\title{
Targeting Hsp70: A possible therapy for cancer
}

Sanjay Kumar ${ }^{1}$, James Stokes III ${ }^{1}$, Udai P. Singh ${ }^{2}$, Karyn Scissum Gunn ${ }^{1}$, Arbind Acharya ${ }^{3}$, Upender Manne $^{4}$, Manoj Mishra ${ }^{1 *}$

${ }^{1}$ Cancer Biology Research and Training Program, Department of Biological Sciences, Alabama State University, AL 36101; ${ }^{2}$ Department of Pathology, Microbiology and Immunology, University of South Carolina School of Medicine, Columbia, SC 29208; ${ }^{3}$ Centre of Advance Study in Zoology, Faculty of Science, Banaras Hindu University, Varanasi221 005, U.P. India. ${ }^{4}$ Department of Pathology, University of Alabama at Birmingham, Birmingham, AL 35294

* Address for Correspondence

Manoj Mishra, Cancer Biology Research and Training Program, Department of Biological Sciences, Alabama State University, AL 36101, USA; Email:mmishra@alasu.edu 


\begin{abstract}
In all organisms, heat-shock proteins (HSPs) provide an ancient defense system. These proteins act as molecular chaperones by assisting proper folding and refolding of misfolded proteins and aid in the elimination of old and damaged cells. HSPs include Hsp100, Hsp90, Hsp70, Hsp40, and small HSPs. Through its substrate-binding domains, Hsp70 interacts with wide spectrum of molecules, ranging from unfolded to natively folded and aggregated proteins, and provides cytoprotective role against various cellular stresses. Under pathophysiological conditions, the high expression of Hsp70 allows cells to survive with lethal injuries. Increased Hsp70, by interacting at several points on apoptotic signaling pathways, leads to inhibition of apoptosis. Elevated expression of Hsp70 in cancer cells may be responsible for tumorigenesis and for tumor progression by providing resistance to chemotherapy. In contrast, inhibition or knockdown of Hsp70 reduces the size of tumors and can cause their complete regression. Moreover, extracellular Hsp70 acts as an immunogen that participates in cross presentation of MHC-I molecules. The goals of this review are to examine the roles of Hsp70 in cancer and to present strategies targeting Hsp70 in the development of cancer therapeutics.
\end{abstract}

Key words: Hsp70, apoptosis, cancer therapeutics, immunogenicity 


\section{Introduction}

In all organisms, the heat-shock response, induced by a wide range of stimuli, increases expression of a family of proteins called heat-shock proteins (HSPs) [1,2] that act as molecular chaperones and, for cells under stress, exhibit cytoprotective properties [3, 4]. Stress beyond a certain threshold induces misfolding and aggregation of proteins and disruption of regulatory complexes [5]. In mammalian cells, the chaperone functions of HSPs maintain and restore cellular homeostasis. Principal heat-shock proteins that have chaperone activity belong to five conserved classes: Hsp33, Hsp60, Hsp70, Hsp90, Hsp100, and the class of small heat-shock proteins (sHSPs). Members of the HSP family, either expressed constitutively or regulated inductively, are transported to various cellular compartments. HSPs of large molecular weight are ATP-dependent molecular chaperones; small HSPs actin an ATP-independent manner. Under physiological conditions, the chaperones also assist in signaling and protein trafficking. However, harmful assaults on cells increase the demand for HSPs (Hsp70 in particular). Among the HSPs, Hsp70 has strong cytoprotective properties. Stress-induced expression of Hsp70 protects cells from lethal injuries and therefore provides a barometer of how pro-apoptotic stimuli elicit a protective response [6-9].

Hsp70 is also involved in cell growth, cell proliferation, and erythroid differentiation during formation of erythrocytes. Accumulation of this protein in erythroblast nuclei protects GATA-1, a transcription factor necessary for erythropoiesis [10]. Malignant cells express higher levels of Hsp70 than normal cells, and high Hsp70 expression is indicative of a tumorigenic phenotype that typically resists chemotherapy and programmed cell death [11-13]. Moreover, Hsp70 interferes at various points on the apoptotic pathways, preventing stress from inappropriately inducing cell death. In addition to its anti-apoptotic function, Hsp70 has an immunomodulatory effect and shows cross presentation with the MHC-I molecule [14]. Hsp70 activates both arms of the immune system (innate and adaptive) and acts as a potent immunomodulator. The goals of the review are to focus on the tumorigenic effects of Hsp70 and potential strategies for treatment of cancers and to assess the immunological role of Hsp70 in cross presentation.

\section{Hsp70: cellular lifeguard}

During periods of stress, human cells produce high levels of Hsp70, constitutively expressed as Hsc70, mitochondrial Hsp75, and GRP78, which are found in the endoplasmic reticulum. Hsp70 
functions as an ATP-dependent molecular chaperone that assists proper folding/refolding of newly synthesized polypeptide chains, assembly of complex structures, and the transport of proteins through the cell membrane [15-20]. Structurally, Hsp70 possesses a peptide binding domain (PBD) and an N-terminal ATPase domain (ABD) (Fig. 1). The EEVD motif in the carboxyl terminal of the PBD is responsible for substrate binding/refolding (Fig. 1). The ABD induces release of client proteins and accomplishes ATP hydrolysis. Upon ATP binding, a proline residue in the ATPase domain induces a conformational change and causes hydrolysis [21]. Several associated co-chaperones also bind to Hsp70 and regulate its chaperone function. The Hsp70-associated co-chaperones are of three types: J-domain co-chaperones (Hsp40 binds to ABD in Hsp70 and stimulates low ATPase activity for this chaperone); the nucleotide exchange factors Bag-1, Hsp110, or HspBP1 catalyze the release of ADP and complete the Hsp70 ATPase cycle; the TPR domain (Hop, CHIP) chaperones bind to the C-terminal EEVD motif of both Hsp70 and Hsp90 [22-24]. These are essential for the assembly of Hsp70 and Hsp90 complexes (Fig. 1) [24].

\section{Please incorporate Fig. 1 here}

Stress-induced expression of Hsp70 allows cells to cope with large amounts of unfolded and/or denatured proteins. Further, the Hsp70 housekeeping functions involve transportation of precursor proteins into cellular comportments; protein folding (cytosol, endoplasmic reticulum, and mitochondria); degradation of unstable proteins and protein complexes; control of regulatory proteins; and protein refolding (Fig. 2) [25].

Please insert Fig. 2 here

\section{Hsp70: an anti-apoptotic protein}

Apoptosis is essential for embryogenesis, development, and maintenance of cellular homeostasis [26, 27]. Anti-cancer drugs induce it through a variety of mechanisms [28]. Either an intrinsic (mitochondria-dependent) or extrinsic (death receptor) pathway facilitates the process. Caspase3 , the effector caspase, is involved in both pathways and is responsible for apoptosis in target cells [29]. 
In response to a death signal, activation of the intrinsic apoptotic pathway results in altered expression of the Bcl2 family of proteins [30]. These include anti-apoptotic (Bcl2 and Bcl-xL); pro-apoptotic (Bax, $\mathrm{Bcl}-\mathrm{Xs}$, and $\mathrm{Bak}$ ); and $\mathrm{BH}_{3}$-only proteins, which function upstream to $\mathrm{Bax}$, Bak, and Bcl-Xs [30-32]. Downstream to mitochondria, released cytochrome c interacts with cytosolic apoptotic protease activation factor-1 (Apaf-1) to form the apoptosome with caspase-9, which leads to activation of caspases [33, 34]. In addition to Bcl2 proteins, Smac/Diablo and Htra2/Omi induce apoptosis by blocking inhibitory apoptotic proteins (Fig. 3) [35-37].

\section{Please insert Fig. 3 here}

Extrinsic apoptosis (the death receptor pathway) is triggered by plasma membrane-associated proteins of the TNF-family of receptors, which lead to activation of caspase-8/10 in the deathinducing signaling complex (DISC) [38]. Caspase-8 either directly activates executioner caspases (caspase-3/6/7) or cleaves Bid into t-Bid, which connects the extrinsic and intrinsic apoptotic pathways [39-41]. In apoptotic signaling, highly expressed Hsp70 interferes at several points, including the release of cytochrome c, activation of caspases, accumulation of misfolded proteins, generation of reactive oxygen species, and DNA fragmentation [13, 42]. Further, inhibition/knockdown of Hsp70 increases sensitivity of cells to apoptosis [43-45]. Hsp70 inhibits caspase activity directly or indirectly, thereby blocking the intrinsic and extrinsic apoptotic pathways through interaction with key apoptotic proteins at three levels: up-stream to mitochondria, at mitochondria, and post-mitochondria (Fig. 3). Thus, Hsp70 directly or indirectly modulates the intrinsic and extrinsic apoptotic pathways.

\section{Hsp70 and the intrinsic apoptotic pathway}

Expression of Hsp70, an evolutionary-conserved protein involved in apoptotic signaling, increases the survivability of cells under stress. Cells with Hsp70 knockdown are sensitive to apoptosis [46]; over-expression of Hsp70 inhibits apoptosis, acting either downstream or upstream to mitochondria.

Furthermore, Hsp70 interacts with nerve growth factor and platelet-derived growth factor and enhances the survival of cells through activation of the PI3K signaling pathway. Activated PI3K leads to activation of ser/thr kinases (Akt/PKB) to generate a growth factor-mediated survival 
signal. Akt kinase targets Bad and caspase-9 in the apoptotic cascade [47-50]. In K562 cells, Hsp70 stabilizes the Akt/PKB complex [51]. In zebra fish, HspA12B, a member of the Hsp70 family, is required for vasculature development, and, by sustaining Akt activity, is involved in endothelial cell migration and tube formation [52]. Thus, members of the Hsp70 family are implicated in the regulation of cell survival and differentiation. Hsp70 is also involved in the rephosphorylation and stabilization of proteins through the priming of non-phosphorylated protein kinases [53]. In NIH3T3 cells, Hsp70 inhibits a stress-activated kinase (apoptosis signal regulating kinase-1), and its down-regulation facilitates production of $\mathrm{H}_{2} \mathrm{O}_{2}, \mathrm{ASK}-1$ activation, and apoptosis [54]. In addition, Hsp70 binds to C-Jun N-terminal kinase (JNK) and blocks its ATP-dependent activation[55]. Mouse embryo fibroblast (MEF) Hsp70.1 $1^{-/-}$cells are resistant to JNK-mediated apoptosis, and AEG 3482, an anti-apoptotic compound, inhibits JNK activity by inducing expression of Hsp70 [56]. In primary cultures of IMR90 human fibroblasts, Hsp70 inhibits P38 kinase [57], which participates in a signaling cascade controlling cellular responses to cytokines and stress.

Hsp70 affects the expression of transcription factors associated with proteins of the Bcl2 family [58]. Bcl2 and Bax are the targets of the tumor suppressor protein, p53. In response to DNA damage, transcription of $\mathrm{Bcl} 2$ is repressed, and Bax is induced [59]. Tumor cells often have a mutated p53, which forms a stable complex with Hsp70/hsc70 [60]. Stress-mediated expression of Hsp70 inhibits the nuclear import of p53 [60, 61]. However, how Hsp70 regulates NF-kBfunction is still poorly understood. Cytosolic Hsp70 could inhibit NF-kB expression, and membrane-bound Hsp70 could induce this transcription factor [62]. In response to similar stimuli, cytosolic and membrane-bound Hsp70 are stimulated [63]. In endothelial cells, stressinduced expression of Hsp70 facilitates TNF- $\alpha$-mediated apoptosis by blocking the NF-kB survival pathway [64]. Furthermore, Hsp70 blocks NF-kB-activation through inhibition of I-kB$\alpha$ kinase (IKK) and degradation of I-kB- $\alpha[65,66]$. Hsp70 may also facilitate the elimination of DNA-damaged cells [67]. Inhibitor of growth (ING) proteins acts as tumor suppressors; their expression is down-regulated in human cancers that transmit a death signal and bind to histones and therefore control chromatin remodeling and p53 activity [68, 69]. These proteins boost the function of Hsp70, which in turn induces TNF- $\alpha$ receptor-mediated apoptosis by preventing IKK activity and blocking of NF-kB survival pathways [68]. In addition, Hsp70 coupled with Hsp40 inhibits Bax translocation and thereby prevents permeabilization of mitochondrial membranes 
and the subsequent release of cytochrome $c$ and apoptosis-inducing factor (AIF) [70]. This function of Hsp70 depends on a chaperone and ATP hydrolysis activity [71].

Hsp70 also acts at the post-mitochondrial level, blocking apoptosis downstream to cytochrome c and upstream to caspase-3 [72]. It inhibits formation of the apoptosome by interaction with its ATPase domain [73, 74]. Furthermore, in TNF- $\alpha$-mediated apoptosis, Hsp70 prevents the characteristic morphological changes of dying cells but does not preclude caspase-3 activation [75]. Activated caspase-3 leads to activation of caspase-activated DNase (CAD), which is responsible for DNA degradation during apoptosis. Hsp70 with its co-chaperones, Hsp40 and inhibitor of CAD (ICAD), regulate enzymatic function and proper folding of CAD. ICAD, with the Hsp70-Hsp40 complex, recognizes and binds to the transit state of CAD and increases its activity in T-cell receptor-mediated T-cells [76]. An early target of caspase-3, poly (ADP-ribose) polymerase (PARP), is necessary to prevent necrosis and inflammation during apoptosis [77, 78]. In the nuclei of cells undergoing single-strand DNA breaks after heat treatment, Hsp70 interacts with PARP1, XRCC1, and other DNA repair proteins [77, 78]. These findings suggest that Hsp70 restores DNA integrity through formation of the protein repair complex. Caspase-3 targets a transcription factor, GATA-1; however, Hsp70 accumulation in nucleus protects GATA-1 from caspase-3 cleavage and thereby increases erythroid cell differentiation and survival [10].

\section{Hsp70 and the extrinsic/death receptor pathway}

Hsp70 blocks TNF- $\alpha$-mediated apoptosis; however, it fails to protect Bid-homozygous knockdown in MEF cells [79]. In primary human fibroblast cells, Hsp70 inhibits Bid cleavage through activation of caspase-8/10 [79]. TNF- $\alpha$ mediated stimulation of hematopoietic cells induces activation of pro-apoptotic, double-stranded RNA-dependent protein kinase (PKR) [80]. In TNF- $\alpha$-induced apoptosis, Hsp70 interacts with the FANCC protein (Fanconianemia complementation group $\mathrm{C}$, an inhibitor of PKR) via its ATPase domain and forms a ternary complex with FANCC and PKR [80, 81]. It also resists TRAIL-induced apoptosis and formation of a death-inducing signaling complex with death receptors DR4 and DR5 [38]. The function of Hsp70 in Fas-induced apoptosis is poorly understood; however, adverse effects depend on the cell context [82, 83]. 


\section{Hsp70 and the caspase-independent apoptotic pathway}

Activation of the intrinsic pathway, triggered by the release of cytochrome c, induces AIF and translocation of endonuclease G (Endo-G) to the nucleus, where it induces caspase-independent nuclear changes [84]. In cells with Apaf-1 and caspase-9 knockdown, Hsp70 inhibits the caspase-independent apoptotic pathway, suggesting that it also prevents cell death in Apaf-1- or caspase-9-knockdown cells incubated with or without a caspase activator/inhibitor. These findings indicate that the cytochrome c/Apaf-1/caspase pathway is not the sole pathway for Hsp70 interactions [85, 86]. In cell-free systems, Hsp70 binds to AIF and inhibits AIF-mediated chromatin condensation, a mechanism by which it could protect cells from AIF-induced apoptosis. Thus, endogenous Hsp70 controls AIF-mediated apoptosis; in Jurkat T cells, downregulation of Hsp70 sensitizes cells to serum withdrawal and AIF release [86]. Further, in Apaf$1^{-/-}$cells, Hsp70 inhibits erythroblast apoptosis by blocking nuclear import of AIF [87]. Hsp70 with Endo-G protects against DNA fragmentation; this association could use AIF as a molecular bridge [88]. Hsp70 resides in the endolysosomal membranes of tumor cells and stressed cells; in HeLa cells, it prevents the release of lysosomal cathepsin into the cytosol (Fig. 3) [89, 90]. Hsp70-positive lysosomes show increased size and resistance to chemical and physical membrane destabilization [91]. In murine fibroblasts, Hsp70 also protects cells from UV-A-and UV-B-induced apoptosis. This protection is mediated through inhibition of IL-6 release, which is induced by UV light (Fig. 3) [91].

\section{Hsp70: a protein associated with tumorigenicity}

Under non-stressed conditions, cells express Hsp70 at basal levels. Enhanced expression, a characteristic of cancerous or stressed cells, increases survival of these cells. Further, anti-cancer therapy elicits Hsp70 expression, which has a cytoprotective effect. Clinical studies indicate that Hsp70 predicts for a poor prognosis because malignant cells express more Hsp70 during tumor progression (endometrial cancers, osteosarcomas, and renal cell tumors) as compared to normal cells [92]. Hsp70 and prostate-specific antigen are markers used to identify patients in early stages of prostate cancer [93]. Further, Hsp70 is abundantly expressed during the progression of chronic myeloid leukemia [94]. In HL-60/BCR-ABL and K562 cells, increased expression of Hsp70 helps cells resist imatinib-mediated cell death (imatinib, a chemotherapeutic agent used to block Bcr-Abl tyrosine kinase activity) [95]. In gastric epithelial cells, the expression of Hsp70 is 
elevated after infection with Helicobacter pylori [95]. In addition, Hsp70.2, a member of the Hsp70 family, is highly expressed during spermatogenesis and breast cancer progression, thereby delaying senescence [95, 96]. Enhanced expression of Hsp70 is associated with tumorigenesis for breast cancer, endometrial cancer, gastric cancer, and acute leukemia; with poor prognoses; and with resistance to chemo-and radiation therapy [13, 97-100]. Nuclear accumulation of Hsp70 is a diagnostic marker for epithelial dysplasia, and antibodies against Hsp70are present in sera of patients with hepatocellular carcinoma [101, 102].

Please insert Table 1 here

Table 1. Demonstrates specific cancers and their association with Hsp70

\begin{tabular}{|c|c|c|c|}
\hline & Cancer Type & Effects of Hsp70 expression & Ref. \\
\hline 1. & $\begin{array}{l}\text { Leukemia, } \\
\text { MCF-7 breast } \\
\text { cancer }\end{array}$ & High Hsp70 expression increase cancer growth and survival & $\begin{array}{l}{[103,} \\
104]\end{array}$ \\
\hline 2. & $\begin{array}{l}\text { Gastric, } \\
\text { endometrial } \\
\text { cancer }\end{array}$ & $\begin{array}{l}\text { Hsp70 silencing with RNAi inhibits human gastric cancer } \\
\text { growth and induces apoptosis }\end{array}$ & $\begin{array}{l}{[105,} \\
106]\end{array}$ \\
\hline 3. & Gastric cancer & High Hsp70expression induced cancer survival & $\begin{array}{l}{[107,} \\
108]\end{array}$ \\
\hline 4. & $\begin{array}{l}\text { Colon and } \\
\text { lung cancer }\end{array}$ & $\begin{array}{l}\text { High Hsp70 expression was associated with overall survival } \\
\text { High Hsp70 plays cytoprotective role in cancer }\end{array}$ & $\begin{array}{l}{[109-} \\
112]\end{array}$ \\
\hline 5. & $\begin{array}{l}\text { Breast \& } \\
\text { Gastric cancer }\end{array}$ & Hsp70 showed anticancer effect & $\begin{array}{l}{[113-} \\
115]\end{array}$ \\
\hline 6. & $\begin{array}{l}\text { Prostate } \\
\text { cancer }\end{array}$ & High Hsp70 contributes in prostate cancer development & $\begin{array}{l}109, \\
116]\end{array}$ \\
\hline
\end{tabular}

Hsp70, which inhibits apoptosis upstream and downstream to mitochondria, is a promising therapeutic target for lowering drug resistance in cancer cells [38, 94]. Stress-mediated expression of Hsp70 promotes tumorigenesis in cancer cells (colon cancer, melanoma, and pancreatic adenocarcinoma); its down-regulation is associated with decreased tumorigenicity [44, 45, 117-119]. In accord with this, a Hsp70 antisense construct was used to kill cancer cells in the absence of additional stimuli [120]. Down-regulation of Hsp70 is cytotoxic to transformed cells; however, it is undetectable in non-transformed cells [118, 121]. Therefore, Hsp70 knockdown sensitizes or kills cancer cells preferentially to normal cells. The constitutively stressed phenotype of cancer cells depends on the cytoprotective function of Hsp70 (Fig. 3). 


\section{Hsp70: cancer treatment}

Hsp70 is a druggable target in comparison to other HSPs because they are regulated by nucleotides [122, 123]. Hsp70/Hsp90 is the only ATPase that is regulated by the inhibition of its ATPase activity $[122,123]$. Therefore, targeting of Hsp70 is an attractive strategy for cancer treatment. Although several inhibitors have been designed for Hsp90, and some of these are in clinical trials, few are known for Hsp70. Gene transcription of Hsp70 is regulated by the transcription factor, HSF1, which becomes activated in response to stress stimuli [124]. Since activated HSF1 induces Hsp70 expression [124], inhibition of HSF1 could be an effective approach to block the expression of Hsp70. Inhibition of HSF1 activation can be achieved by the flavonoid, quercetin; by diterpenetriperoxide; and by triptolide. These compounds, along with benzopyrene, inhibit the expression of Hsp70; other HSPs may remain unaffected [43, 125-129]. In K562 cells, resveratrol, a non-specific inhibitor of Hsp70, inhibits Hsp70 expression by blocking Akt-kinase activity and up-regulating ERK1/2 kinase activity [130].

\section{Please insert Fig. 4 here}

AIF-derived peptides (150-228aa) targeting Hsp70 sensitize cancer cells to apoptosis [131]. These peptides carry the AIF regions (150aa-228aa) required for Hsp70 binding in its PBD but lack the pro-apoptotic function of AIF. One of these inhibitors, ADD70 (AIF-derived decoy for Hsp70) decreases tumor sizes in rat colon cancers and melanomas (B16F10) and sensitizes these cancers to cisplatin. ADD70 shows anti-tumor effects in syngeneic animals but not in immunodeficient mice; it also increases tumor-infiltrating cytotoxic $\mathrm{CD}^{+} \mathrm{T}$-cells [121].

In lymphoma cells, interaction of a small molecule (HS-72) with Hsp70 leads to aggregation of misfolded proteins and destabilization of lysosome membranes, thus inducing autophagic cell death [132]. 2-Phenylacetylene sulfonamide interacts with the C-terminal of Hsp70 and inhibits its expression [133]. In B-CCL cells, however, PES induces the caspase-dependent apoptotic pathway [134]. Hsp90 inhibitors that displace ATP from Hsp70 may target Hsp70. Although further investigations are needed to explore the underlying mechanisms, some results are encouraging [135]. The adenosine-derived compound, VEK-155008, targets the ATPase domain of Hsp70/hsc70 and blocks its chaperone activity; it also induces death of colon HCT116 carcinoma cells [136]. To date, however, no evidence derived with intact animals is available. 
Although azure $\mathrm{C}$, methylene blue, and myricetin are potent inhibitors of human Hsp70, their specificity for tumor-derived Hsp70 remains to be addressed [137].

Please insert Table 2 here

Table 2. Demonstrates various Hsp70 inhibitors including their sites of action and applications in pre-clinical and clinical trials. Dotted lines show that the given compound may or may not be beneficial in clinical trials.

\begin{tabular}{|c|c|c|c|c|}
\hline & Hsp70 inhibitors & Site of interaction & $\begin{array}{l}\text { Tested in } \\
\text { Clinical trials }\end{array}$ & Ref. \\
\hline 1. & MKT-077 & $\begin{array}{l}\text { N-terminal ATP binding } \\
\text { domain }\end{array}$ & Yes & {$[122,123]$} \\
\hline \multirow[t]{5}{*}{2.} & Dihydropyrimidines & $\begin{array}{l}\text { N-terminal ATP binding } \\
\text { domain }\end{array}$ & ....... & \multirow{5}{*}{$\begin{array}{l}{[122,} \\
123,137] \\
{[124,125]}\end{array}$} \\
\hline & i) $\mathrm{SW} 02$ & $\begin{array}{l}\text { N-terminal ATP binding } \\
\text { domain }\end{array}$ & Yes & \\
\hline & ii) MAL2-IIB & $\begin{array}{l}\text { N-terminal ATP binding } \\
\text { domain }\end{array}$ & Yes & \\
\hline & iii) MAL3-101 & $\begin{array}{l}\text { N-terminal ATP binding } \\
\text { domain }\end{array}$ & Yes & \\
\hline & iv)NSC630668-R/I & $\begin{array}{l}\text { N-terminal ATP binding } \\
\text { domain }\end{array}$ & $\ldots \ldots$ & \\
\hline \multirow[t]{4}{*}{3.} & Sulfoglycolipids & $\begin{array}{l}\text { N-terminal ATP binding } \\
\text { domain }\end{array}$ & ....... & \multirow{4}{*}{$\begin{array}{l}{[122,} \\
123,138, \\
139]\end{array}$} \\
\hline & $\begin{array}{l}\text { i) Sulfogalactoglycerolipi } \\
\text { d }\end{array}$ & $\begin{array}{l}\text { N-terminal ATP binding } \\
\text { domain }\end{array}$ & $\ldots \ldots$ & \\
\hline & $\begin{array}{l}\text { ii) Sulfogalactosylceramid } \\
\mathrm{e}\end{array}$ & $\begin{array}{l}\text { N-terminal ATP binding } \\
\text { domain }\end{array}$ & $\ldots \ldots$ & \\
\hline & iii) adamantylSGC & $\begin{array}{l}\text { N-terminal ATP binding } \\
\text { domain }\end{array}$ & $\ldots \ldots$ & \\
\hline \multirow[t]{3}{*}{4.} & Flavonoids & $\begin{array}{l}\text { N-terminal ATP binding } \\
\text { domain }\end{array}$ & $\ldots \ldots$ & \multirow{3}{*}{$\begin{array}{l}{[122,} \\
123,137, \\
140]\end{array}$} \\
\hline & i) Epigallocatechin & $\begin{array}{l}\text { N-terminal ATP binding } \\
\text { domain }\end{array}$ & Yes & \\
\hline & ii) Myricetin & $\begin{array}{l}\text { N-terminal ATP binding } \\
\text { domain }\end{array}$ & $\cdots \cdots$ & \\
\hline 5. & Apoptozole & $\begin{array}{l}\text { N-terminal ATP binding } \\
\text { domain }\end{array}$ & ....... & $\begin{array}{l}122, \\
123,141]\end{array}$ \\
\hline 6. & VEK-155008 & $\begin{array}{l}\text { N-terminal ATP binding } \\
\text { domain }\end{array}$ & $\ldots \ldots \ldots$ & [122] \\
\hline 7. & Aptamer A17 & $\begin{array}{l}\text { N-terminal ATP binding } \\
\text { domain }\end{array}$ & $\ldots \ldots \ldots$ & $\begin{array}{l}{[122,} \\
123]\end{array}$ \\
\hline 8. & $\begin{array}{l}\text { Dibenzyl-8- } \\
\text { aminoadenosine analog }\end{array}$ & $\begin{array}{l}\text { N-terminal ATP binding } \\
\text { domain }\end{array}$ & $\ldots \ldots \ldots$ & $\begin{array}{l}{[122,} \\
123]\end{array}$ \\
\hline 9. & $\mathrm{cmHsp} 70.1 \mathrm{mAb}$ & Interact with Hsp70 epitope & Yes & {$[122$,} \\
\hline
\end{tabular}




\begin{tabular}{|c|c|c|c|}
\hline & & & $123,142]$ \\
\hline 10. $\quad$ PES & $\begin{array}{l}\text { C-terminal/peptide binding } \\
\text { domain }\end{array}$ & Yes & $\begin{array}{l}{[122} \\
123]\end{array}$ \\
\hline 11. Pyrrhocoricin & $\begin{array}{l}\text { C-terminal/peptide binding } \\
\text { domain }\end{array}$ & ....... & $\begin{array}{l}{[122,} \\
123,143]\end{array}$ \\
\hline 12. Geranylgeranylacetone & $\begin{array}{l}\text { C-terminal/peptide binding } \\
\text { domain }\end{array}$ & Yes & $\begin{array}{l}{[122,} \\
123,144]\end{array}$ \\
\hline 13. Fatty acid acyl benzamides & $\begin{array}{l}\text { C-terminal/peptide binding } \\
\text { domain }\end{array}$ & ....... & $\begin{array}{l}{[122,} \\
123,145]\end{array}$ \\
\hline 14. $\quad$ Pifichrin- $\mu$ & $\begin{array}{l}\text { C-terminal/peptide binding } \\
\text { domain }\end{array}$ & $\ldots \ldots$ & $\begin{array}{l}{[122,} \\
123,132]\end{array}$ \\
\hline 15. aptamerA8 & $\begin{array}{l}\text { C-terminal/peptide binding } \\
\text { domain }\end{array}$ & $\cdots \cdots$ & $\begin{array}{l}{[122,} \\
123]\end{array}$ \\
\hline
\end{tabular}

MKT-077, a cationic rhodacyanine dye, acts upon ABD-Hsp70 in cancer cells. This compound, which migrates to mitochondria and inhibits mitochondrial Hsp70, is being tested in Phase-I clinical trials as an anticancer agent [146]. Although MKT-077 does not interact with Hsp70, it deserves further investigation due to its drug-like nature [147]. NSC 630668, a dihydropyrimidine, and a second-generation compound, MAL3-101, inhibit the ATPase activity of Hsp70 and the proliferation of SK-BK-3 cancer cells [148]. MAL2-11B, an inhibitor of polyomavirus, blocks the activity of the viral J-domain protein and T-antigen; further investigations are needed to dissect this process [149]. The combination of peptide aptamers consisting of an E. coli thioredoxin scaffold shows (8aa or 13aa) peptide loops that block Hsp70 expression by interacting with the ATP-binding domain of Hsp70, as determined in yeast 2hybrid systems. Among these, A17 induces apoptosis in tumors in response to anti-cancer drugs. It inhibits the chaperone activity of Hsp70 but has no effect on Hsp70/Hsp90 [131].

Several synthetic compounds disrupt the interaction between Hsp70 and its co-chaperones. Active in this regard are pyrimidotriazinediones, a new class of drugs that interact with Hop/Hsp70 and are toxic to WST-1 cells [150]. Drugs targeting huntingtin-interacting protein 1 block Hsp70-chaperone activity and stimulate neurodegeneration [151].

Targeting Hsp70 is a new therapeutic approach; most compounds active in this regard are Hsp90/Hsp70 inhibitors that induce apoptosis in cancer cells [46, 121]. Various HSP inhibitors are being evaluated in clinical trials. In treated patients, however, there is enhanced expression of Hsp70 in cancer cells, which is not a positive sign, for Hsp70 accumulation reduces the possibility of cell death, thus decreasing the anti-tumor efficacy of Hsp70 inhibitors. Treatment 
with chemotherapeutic drugs increases the expression of Hsp70 and induces TGF- $\beta$-signaling [152]. Hsp70 knockdown by siRNA increases sensitivity of cancer cells to tanespimycin (17-Nallylamino-17-demethoxygeldanamycin, 17-AAG) [153]. However, in HCT116 cells, knockdown of both Hsp70 and Hsc70 induces proteosomal-dependent degradation of Hsp90 client proteins and apoptosis [154]. In addition, a combination of an adenosine-derived inhibitor of Hsp70, VER-155008, and 17-AAG induces apoptosis in HCT116 colon carcinoma cells [136]. Furthermore, the anti-cancer activity of 17-AAG is elevated in colon cancer cells with blocked Hsp70 [121].

Inhibitors of Hsp70 and Hsp90 combined with histone deacetylase inhibitors increase the cell surface expression of Hsp70 on hematopoietic cancer cells [155]. An early response of extracellular Hsp70 is to activate suppressive myeloid immune cells [156]. Therefore, Hsp70 and Hsp90 inhibitors should be evaluated for a synergistic effect in an experimental model (Fig. 4). Chelerythrine, a benzophenenthridine alkaloid and a specific inhibitor of protein kinase C (PKC), downregulates the expression of Hsp70 in Dalton's lymphoma cells [157, 158]. Staurosporine, a non-specific inhibitor of PKC, also shows a similar effect [158].

\section{Hsp70: Immunological function}

In addition, to cytoprotection and chaperone activity, tumor-derived Hsp70 has immunomodulatory function(s) that activate the immune system. The immunogenic function of tumor derived/exogenous Hsp70 is exerted through its antigenic peptides [159].

In humans, the tumor burden enhances the expression of serum Hsp70, and tumor cells are the natural reservoir of Hsp70. Hsp70 is abundantly expressed on tumor cell surfaces during tumor progression; however, treatment with interferon- $\gamma$ induces the release of Hsc70 from tumor cells $[160,161]$. Furthermore, members of the Hsp70 family often infiltrate antigen-presenting cells (APCs) and are present in neuroblastomas and lung and colon adenocarcinomas [136, 162].

\section{Please insert Fig. 5 here}

Cytosolic Hsp70 is transported to the plasma membrane in association with other proteins that possess a transmembrane domain. However, lack of a leader peptide does not allow Hsp70 to localize on the membrane in that manner. A possibility is that Hsp70 interacts with lipids in/on the membrane. In PC12 tumor cells, Hsp70 interacts with phosphatidylserine (PS) and shows co- 
localization with PS in the outer membrane leaflet, which is facilitated by a P-flipping mechanism [163]. There are two possible mechanisms by which Hsp70 is released from cells: a passive mechanism that results from necrosis, trauma, or surgery, and/or an active mechanism by which non-classical proteins are released from immunologically potent exosomes [164, 165]. In HepG2 cells, Hsp70 is released from the extracellular environment after heat shock. Membranebound Hsp70acts as an activator of macrophages, free recombinant Hsp70 does not [166].

Hsp70 shows immunogenicity that activates both arms of the immune system (innate and adaptive immune responses) $[167,168]$. In a receptor-mediated manner, endocytosis of Hsp70 stimulates the MHC-I presentation pathway of professional APCs and cytotoxic T-lymphocytes [72]. Thus, tumor-derived Hsp70 can be used as a tumor-specific vaccine [169]. Hsp70 also induces the release of pro-inflammatory cytokines from innate immune cells, thereby increasing the expression of co-stimulatory molecules $[162,170]$. Furthermore, Hsp70 activates the lytic machinery of natural killer (NK) cells against tumors expressing Hsp70 on the cell surface [171]. These characteristics of Hsp70 have led to the view that Hsp70 acts as an endogenous adjuvant and immunological danger signal [172].

Hsp70 and Hsp90 are regulators of the immune system. Hsp70 elicits anti-cancer immune responses, but Hsc70 does not [173]. Therefore, Hsp70 is the foundation of immunogenicity; following cross presentation of tumor-derived Hsp70 on MHC-I molecules, a T-cell response is generated [174-181]. Hsp70 enters into the endogenous antigen-processing pathway, primes $\mathrm{CD}^{+} \mathrm{T}$ cells for antigen production, and becomes involved in cross presentation [181-184]. Tumor-derived Hsp70 is endocytosed by APCs with the help of HSP receptors (CD91, CD40, TLR2/4 + CD14, CD35, Lox-1, and SR-A) and presented on the MHC-I molecule, thereby producing a CD8+ T-cell response against cancerous stimuli. Recombinant Hsp70 induces cross presentation via the formation of various complexes and the uptake of antigens. However, recombinant Hsp70 does not stimulate innate immune responses in dendritic or B cells [185]. However, tumor-derived Hsp70 enhances MHC-II restricted peptide presentation and CD4 ${ }^{+} \mathrm{T}$ cell activation [186]. In the absence of immunogenic antigens, Hsp70 gives danger signals for the immune system [187]. Therefore, Hsp70 apparently inhibits tumor growth via two pathways: one antigen-dependent and the other antigen-independent. The C-terminal domain of Hsp70 typically produces an antigen-independent response, which includes stimulation of NK cells against tumor challenges [63]. Treatment with Hsp70 results in a stronger anti-tumor response 
[188]. Hsp70 also affects cytokines. In APCs, Hsp70 induces the release of pro-inflammatory cytokines, including IL-1 $\beta$, IL-6, and TNF- $\alpha$ [63]. In established melanomas, Hsp70 acts as an immune adjuvant that induces TNF- $\alpha$ production [189]. The role of Hsp70 in cytokine production has been studied (Fig. 5) [53, 159, 190].

\section{Hsp70: an immunotherapeutic drug}

On the basis of its immunological function, Hsp70 can be used as an immunotherapeutic drug because its potent adjuvant nature induces cancer autoimmunity [191]. Hsp70 derived from A-20 leukemic cells acts as an antigen and induces the production of anA-20-specific antibody, resulting in complement-dependent cytotoxicity against these cells [192]. Further, dendritic cells pulsed with Hsp70 induce immunity against B-16 melanoma, which increases the therapeutic value of a Cox-2 inhibitor [193]. The C-terminus of Hsp70 interacts with $\mathrm{CD}^{+} \mathrm{T}^{\mathrm{T}}$ and $\mathrm{CD} 4^{+} \mathrm{T}$ cell epitopes and enhances tumor immunity beyond the effect of the $\mathrm{CD} 8^{+} \mathrm{T}$ cell epitope alone in eliminating tumor cells $[159,194]$. In experimental models, a similar interaction with HPV-16 E7 induces an antigen-specific cytotoxic T-cell response [195]. C-terminal interaction of Hsp70 with a recombinant $\mathrm{N}$-domain calreticulin/E7 generates an antitumor immune response [195]. Although some HSP-based vaccines are currently being used in clinical practice, an improved formulation of these vaccines may derived by extraction and use of the Hsp70 complex from dendritic tumor-fused cells [141]. Hsp70-based vaccines derived from the fusions of dendritic and tumor cells reverse immunotolerance of cancers more efficiently than vaccines derived from tumor cells alone [196]. Autologous anti-tumor vaccines prepared with hydroxyapatite particles and Hsp70/27/Grp96 can be used safely [197, 198]. NK cells, which are effectors of innate immune responses, are involved in anti-tumor immunity produced by vaccinations with chaperone-rich cell lysates [199]. Hsp70 induces activation of NK cells [200]. A14-mer peptide (TKD), derived from the C-terminal of Hsp70 (PBD) 450aa-463aa, shows similar immunostimulatory capabilities on NK-cells as full-length Hsp70 [201, 202]. NK cells incubated with a cytokine plus soluble Hsp70 or the TKD peptide enhance expression of the activating receptor (CD14) and increase migration capacity [200]. Hsp70, present on tumor cell surfaces but not on surfaces of normal cells, is considered as a tumor-selective target. In a mouse model, peripheral blood lymphocytes incubated with TKD-peptide and IL-2 induce migration of NK cells towards Hsp70 membrane-positive tumor cells [203]. An Hsp70-based vaccine is in phase-I 
clinical trials; an advantage of this approach is the excellent safety and the bioavailability of the synthetic Hsp70 peptide that stimulates NK-cells [204].

\section{Conclusions}

Hsp70 is the most ancient anti-stress defensive system that promotes tumor cell survival by interacting at several points in apoptotic signaling pathway(s) [109-112]. Researchers are attempting to improve modern cancer treatment therapies by implementing Hsp70 inhibitors for the development of novel drugs in the near future [113-115]. Hsp70 demonstrates various functions, including acting as a cellular lifeguard and exerting anti-apoptotic effects. It is also involved in modulation of intrinsic and extrinsic apoptotic signaling and, in cancer cells, modulates caspase-independent apoptosis. Since Hsp70 has anti-cancer and immunogenic properties, there is a search for Hsp70 inhibitors. However, preclinical and clinical evaluations have not yet been accomplished, unlike Hsp90 inhibitors, which are already in phase II/III clinical trials. Nevertheless, clinical trial results obtained to date are not favorable. Such results may be due to enhanced expression of Hsp70 in tumors. Extracellular Hsp70 is believed to be immunogenic because it acts as an adjuvant and, combined with chaperone(s), it may prove useful for vaccine production and cancer treatment. Increased expression of extracellular Hsp70 is a sign of a poor prognosis for cancer. In syngeneic mice, inhibition or depletion of Hsp70 causes tumor regression, and Hsp70 inhibition results in an anti-tumor immune response and apoptosis of the target cells. Therefore, targeting Hsp70 is a promising therapy for cancer patients.

\section{Acknowledgements:}

We thank Dr. Donald Hill for his critical review of the manuscript. The authors have been partially supported by National Institutes of Health grants P20CA192976 (MKM) and P20CA192973 (UM); US Department of Defense grants W911NF-12-1-0073 (MKM) and W911NF-14-1-0064 (MKM); and National Science Foundation grant 1154214 (MKM). 


\section{Figure Legends}

Fig. 1 Structure of Hsp70 with sites of action [22-24]. N-terminal shows ATPase domain with associated co-chaperones (Bag1/Hip/hsp110 or hspBP1). However, C-terminal represents EEVD domain with its co-chaperone (Hop/Hdj-1/Chip) and peptide binding domain. J-domain localizes in the central approximately.

Fig. 2 Diagrammatic presentation of the chaperone functions of Hsp70 [22-25]. Hsp70 binds to unfolded protein in the presence of J-proteins using ATP. ATP hydrolysis stimulates J-protein release that further led to release of correctly folded protein(s) and Hsp70 become available for next cycle.

Fig. 3 Schematic representation of the function of Hsp70 in the apoptotic signaling and survival pathways [205-208]. SAPKs stimulate synthesis of Hsp70 that leads to cell survival. High Hsp70 interferes at several levels in the apoptotic signaling such as apoptosome, caspases, and cathepsins. Hsp70 also contributes in heterodimerization of bcl2 and Bcl-xL that block Bax heterodimerization.

Fig. 4 Schematic representation of the inhibition of Hsp70 in cell survival pathways [159, 181, 209]. Hsp70 can be inhibited at transcription and post-transcription levels as indicated in the figure. Inhibition of Hsp70 may results in induction of cell death.

Fig. 5 Diagram depicting involvement of Hsp 70 in cross presentation [159, 181, 209]. Receptor mediated endocytosis of Hsp70 was presented by MHC-II in association with $\mathrm{CD} 4{ }^{+} \mathrm{T}$ cells. However, small fragments of Hsp70 was presented by MHC-I molecule in association with $\mathrm{CD}^{+} \mathrm{T}$ cells, called "cross presentation". 


\section{References}

[1] A. Tissieres, H.K. Mitchell, U.M. Tracy, Protein synthesis in salivary glands of Drosophila melanogaster: relation to chromosome puffs, J Mol Biol, 84 (1974) 389-398.

[2] H. Kroeger, The induction of new puffing patterns by transplantation of salivary gland nuclei into egg cytoplasma of Drosophila, Chromosoma, 11 (1960) 129-145.

[3] G.C. Li, Z. Werb, Correlation between synthesis of heat shock proteins and development of thermotolerance in Chinese hamster fibroblasts, Proc Natl Acad Sci U S A, 79 (1982) 32183222.

[4] M.J. Gething, J. Sambrook, Protein folding in the cell, Nature, 355 (1992) 33-45.

[5] I. Yahara, Stress-inducible cellular responses. Introduction, EXS, 77 (1996) XI-XII.

[6] A. Parcellier, S. Gurbuxani, E. Schmitt, E. Solary, C. Garrido, Heat shock proteins, cellular chaperones that modulate mitochondrial cell death pathways, Biochem Biophys Res Commun, 304 (2003) 505-512.

[7] E.A. Nollen, J.F. Brunsting, H. Roelofsen, L.A. Weber, H.H. Kampinga, In vivo chaperone activity of heat shock protein 70 and thermotolerance, Mol Cell Biol, 19 (1999) 2069-2079.

[8] B.S. Polla, S. Kantengwa, D. Francois, S. Salvioli, C. Franceschi, C. Marsac, A. Cossarizza, Mitochondria are selective targets for the protective effects of heat shock against oxidative injury, Proc Natl Acad Sci U S A, 93 (1996) 6458-6463.

[9] H.S. Park, S.G. Cho, C.K. Kim, H.S. Hwang, K.T. Noh, M.S. Kim, S.H. Huh, M.J. Kim, K. Ryoo, E.K. Kim, W.J. Kang, J.S. Lee, J.S. Seo, Y.G. Ko, S. Kim, E.J. Choi, Heat shock protein hsp72 is a negative regulator of apoptosis signal-regulating kinase 1, Mol Cell Biol, 22 (2002) 7721-7730.

[10] J.A. Ribeil, Y. Zermati, J. Vandekerckhove, S. Cathelin, J. Kersual, M. Dussiot, S. Coulon, I.C. Moura, A. Zeuner, T. Kirkegaard-Sorensen, B. Varet, E. Solary, C. Garrido, O. Hermine, Hsp70 regulates erythropoiesis by preventing caspase-3-mediated cleavage of GATA-1, Nature, 445 (2007) 102-105.

[11] M. Jaattela, Heat shock proteins as cellular lifeguards, Ann Med, 31 (1999) 261-271.

[12] A.L. Rerole, G. Jego, C. Garrido, Hsp70: anti-apoptotic and tumorigenic protein, Methods Mol Biol, 787 (2011) 205-230.

[13] C. Garrido, M. Brunet, C. Didelot, Y. Zermati, E. Schmitt, G. Kroemer, Heat shock proteins 27 and 70: anti-apoptotic proteins with tumorigenic properties, Cell cycle, 5 (2006) 2592-2601.

[14] L. Elsner, P.F. Flugge, J. Lozano, V. Muppala, B. Eiz-Vesper, S.Y. Demiroglu, D. Malzahn, T. Herrmann, E. Brunner, H. Bickeboller, G. Multhoff, L. Walter, R. Dressel, The endogenous danger signals HSP70 and MICA cooperate in the activation of cytotoxic effector functions of NK cells, J Cell Mol Med, 14 (2010) 992-1002.

[15] M. Jaattela, Escaping cell death: survival proteins in cancer, Exp Cell Res, 248 (1999) 3043.

[16] M. Tavaria, T. Gabriele, I. Kola, R.L. Anderson, A hitchhiker's guide to the human Hsp70 family, Cell Stress Chaperones, 1 (1996) 23-28.

[17] M. Daugaard, M. Rohde, M. Jaattela, The heat shock protein 70 family: Highly homologous proteins with overlapping and distinct functions, FEBS Lett, 581 (2007) 3702-3710.

[18] R.P. Beckmann, L.E. Mizzen, W.J. Welch, Interaction of Hsp 70 with newly synthesized proteins: implications for protein folding and assembly, Science, 248 (1990) 850-854.

[19] H. Murakami, D. Pain, G. Blobel, 70-kD heat shock-related protein is one of at least two distinct cytosolic factors stimulating protein import into mitochondria, J Cell Biol, 107 (1988) 2051-2057. 
[20] Y. Shi, J.O. Thomas, The transport of proteins into the nucleus requires the 70-kilodalton heat shock protein or its cytosolic cognate, Mol Cell Biol, 12 (1992) 2186-2192.

[21] M. Vogel, B. Bukau, M.P. Mayer, Allosteric regulation of Hsp70 chaperones by a proline switch, Mol Cell, 21 (2006) 359-367.

[22] F. Hennessy, W.S. Nicoll, R. Zimmermann, M.E. Cheetham, G.L. Blatch, Not all J domains are created equal: implications for the specificity of Hsp40-Hsp70 interactions, Protein Sci, 14 (2005) 1697-1709.

[23] J.C. Young, V.R. Agashe, K. Siegers, F.U. Hartl, Pathways of chaperone-mediated protein folding in the cytosol, Nat Rev Mol Cell Biol, 5 (2004) 781-791.

[24] C. Ramos, Molecular chaperones and protein quality control, Protein Pept Lett, 18 (2011) 100.

[25] W. Voos, A new connection: chaperones meet a mitochondrial receptor, Mol Cell, 11 (2003) 1-3.

[26] J.F. Kerr, A.H. Wyllie, A.R. Currie, Apoptosis: a basic biological phenomenon with wideranging implications in tissue kinetics, Br J Cancer, 26 (1972) 239-257.

[27] E.H. Baehrecke, How death shapes life during development, Nat Rev Mol Cell Biol, 3 (2002) 779-787.

[28] E. Solary, N. Droin, A. Bettaieb, L. Corcos, M.T. Dimanche-Boitrel, C. Garrido, Positive and negative regulation of apoptotic pathways by cytotoxic agents in hematological malignancies, Leukemia, 14 (2000) 1833-1849.

[29] C.J. Hess, J. Berkhof, F. Denkers, G.J. Ossenkoppele, J.P. Schouten, J.J. Oudejans, Q. Waisfisz, G.J. Schuurhuis, Activated intrinsic apoptosis pathway is a key related prognostic parameter in acute myeloid leukemia, J Clin Oncol, 25 (2007) 1209-1215.

[30] W.X. Zong, T. Lindsten, A.J. Ross, G.R. MacGregor, C.B. Thompson, BH3-only proteins that bind pro-survival Bcl-2 family members fail to induce apoptosis in the absence of Bax and Bak, Genes Dev, 15 (2001) 1481-1486.

[31] D.G. Breckenridge, D. Xue, Regulation of mitochondrial membrane permeabilization by BCL-2 family proteins and caspases, Curr Opin Cell Biol, 16 (2004) 647-652.

[32] E.H. Cheng, M.C. Wei, S. Weiler, R.A. Flavell, T.W. Mak, T. Lindsten, S.J. Korsmeyer, BCL-2, BCL-X(L) sequester BH3 domain-only molecules preventing BAX- and BAK-mediated mitochondrial apoptosis, Mol Cell, 8 (2001) 705-711.

[33] P. Li, D. Nijhawan, I. Budihardjo, S.M. Srinivasula, M. Ahmad, E.S. Alnemri, X. Wang, Cytochrome $\mathrm{c}$ and dATP-dependent formation of Apaf-1/caspase-9 complex initiates an apoptotic protease cascade, Cell, 91 (1997) 479-489.

[34] B. Zhivotovsky, S. Orrenius, O.T. Brustugun, S.O. Doskeland, Injected cytochrome c induces apoptosis, Nature, 391 (1998) 449-450.

[35] C. Du, M. Fang, Y. Li, L. Li, X. Wang, Smac, a mitochondrial protein that promotes cytochrome c-dependent caspase activation by eliminating IAP inhibition, Cell, 102 (2000) 3342.

[36] A.M. Verhagen, D.L. Vaux, Cell death regulation by the mammalian IAP antagonist Diablo/Smac, Apoptosis, 7 (2002) 163-166.

[37] E.M. Creagh, B.M. Murphy, P.J. Duriez, C.S. Duckett, S.J. Martin, Smac/Diablo antagonizes ubiquitin ligase activity of inhibitor of apoptosis proteins, J Biol Chem, 279 (2004) 26906-26914.

[38] F. Guo, C. Sigua, P. Bali, P. George, W. Fiskus, A. Scuto, S. Annavarapu, A. Mouttaki, G. Sondarva, S. Wei, J. Wu, J. Djeu, K. Bhalla, Mechanistic role of heat shock protein 70 in Bcr- 
Abl-mediated resistance to apoptosis in human acute leukemia cells, Blood, 105 (2005) 12461255.

[39] M. Muzio, Signalling by proteolysis: death receptors induce apoptosis, Int J Clin Lab Res, 28 (1998) 141-147.

[40] X. Luo, I. Budihardjo, H. Zou, C. Slaughter, X. Wang, Bid, a Bcl2 interacting protein, mediates cytochrome $\mathrm{c}$ release from mitochondria in response to activation of cell surface death receptors, Cell, 94 (1998) 481-490.

[41] K. Schulze-Osthoff, D. Ferrari, M. Los, S. Wesselborg, M.E. Peter, Apoptosis signaling by death receptors, Eur J Biochem, 254 (1998) 439-459.

[42] D.D. Mosser, A.W. Caron, L. Bourget, A.B. Meriin, M.Y. Sherman, R.I. Morimoto, B. Massie, The chaperone function of hsp70 is required for protection against stress-induced apoptosis, Mol Cell Biol, 20 (2000) 7146-7159.

[43] A. Aghdassi, P. Phillips, V. Dudeja, D. Dhaulakhandi, R. Sharif, R. Dawra, M.M. Lerch, A. Saluja, Heat shock protein 70 increases tumorigenicity and inhibits apoptosis in pancreatic adenocarcinoma, Cancer Res, 67 (2007) 616-625.

[44] S. Gurbuxani, J.M. Bruey, A. Fromentin, N. Larmonier, A. Parcellier, M. Jaattela, F. Martin, E. Solary, C. Garrido, Selective depletion of inducible HSP70 enhances immunogenicity of rat colon cancer cells, Oncogene, 20 (2001) 7478-7485.

[45] J. Nylandsted, M. Rohde, K. Brand, L. Bastholm, F. Elling, M. Jaattela, Selective depletion of heat shock protein 70 (Hsp70) activates a tumor-specific death program that is independent of caspases and bypasses Bcl-2, Proc Natl Acad Sci U S A, 97 (2000) 7871-7876.

[46] E. Schmitt, A. Parcellier, S. Gurbuxani, C. Cande, A. Hammann, M.C. Morales, C.R. Hunt, D.J. Dix, R.T. Kroemer, F. Giordanetto, M. Jaattela, J.M. Penninger, A. Pance, G. Kroemer, C. Garrido, Chemosensitization by a non-apoptogenic heat shock protein 70-binding apoptosisinducing factor mutant, Cancer Res, 63 (2003) 8233-8240.

[47] W.H. Biggs, 3rd, J. Meisenhelder, T. Hunter, W.K. Cavenee, K.C. Arden, Protein kinase $\mathrm{B} /$ Akt-mediated phosphorylation promotes nuclear exclusion of the winged helix transcription factor FKHR1, Proc Natl Acad Sci U S A, 96 (1999) 7421-7426.

[48] O.N. Ozes, L.D. Mayo, J.A. Gustin, S.R. Pfeffer, L.M. Pfeffer, D.B. Donner, NF-kappaB activation by tumour necrosis factor requires the Akt serine-threonine kinase, Nature, 401 (1999) $82-85$.

[49] S.R. Datta, H. Dudek, X. Tao, S. Masters, H. Fu, Y. Gotoh, M.E. Greenberg, Akt phosphorylation of BAD couples survival signals to the cell-intrinsic death machinery, Cell, 91 (1997) 231-241.

[50] M.H. Cardone, N. Roy, H.R. Stennicke, G.S. Salvesen, T.F. Franke, E. Stanbridge, S. Frisch, J.C. Reed, Regulation of cell death protease caspase- 9 by phosphorylation, Science, 282 (1998) 1318-1321.

[51] T. Gao, A.C. Newton, The turn motif is a phosphorylation switch that regulates the binding of Hsp70 to protein kinase C, J Biol Chem, 277 (2002) 31585-31592.

[52] G. Hu, J. Tang, B. Zhang, Y. Lin, J. Hanai, J. Galloway, V. Bedell, N. Bahary, Z. Han, R. Ramchandran, B. Thisse, C. Thisse, L.I. Zon, V.P. Sukhatme, A novel endothelial-specific heat shock protein HspA12B is required in both zebrafish development and endothelial functions in vitro, J Cell Sci, 119 (2006) 4117-4126.

[53] B. Gao, M.F. Tsan, Recombinant human heat shock protein 60 does not induce the release of tumor necrosis factor alpha from murine macrophages, J Biol Chem, 278 (2003) 2252322529. 
[54] V.L. Gabai, J.A. Yaglom, V. Volloch, A.B. Meriin, T. Force, M. Koutroumanis, B. Massie, D.D. Mosser, M.Y. Sherman, Hsp72-mediated suppression of c-Jun N-terminal kinase is implicated in development of tolerance to caspase-independent cell death, Mol Cell Biol, 20 (2000) 6826-6836.

[55] D.D. Mosser, R.I. Morimoto, Molecular chaperones and the stress of oncogenesis, Oncogene, 23 (2004) 2907-2918.

[56] J.S. Lee, J.J. Lee, J.S. Seo, HSP70 deficiency results in activation of c-Jun N-terminal Kinase, extracellular signal-regulated kinase, and caspase-3 in hyperosmolarity-induced apoptosis, J Biol Chem, 280 (2005) 6634-6641.

[57] V.L. Gabai, K. Mabuchi, D.D. Mosser, M.Y. Sherman, Hsp72 and stress kinase c-jun Nterminal kinase regulate the bid-dependent pathway in tumor necrosis factor-induced apoptosis, Mol Cell Biol, 22 (2002) 3415-3424.

[58] B. Jiang, P. Liang, G. Deng, Z. Tu, M. Liu, X. Xiao, Increased stability of Bcl-2 in HSP70mediated protection against apoptosis induced by oxidative stress, Cell Stress Chaperones, 16 (2011) 143-152.

[59] D.L. Crowe, U.K. Sinha, p53 apoptotic response to DNA damage dependent on bc12 but not bax in head and neck squamous cell carcinoma lines, Head Neck, 28 (2006) 15-23.

[60] M. Zylicz, F.W. King, A. Wawrzynow, Hsp70 interactions with the p53 tumour suppressor protein, EMBO J, 20 (2001) 4634-4638.

[61] S. Akakura, M. Yoshida, Y. Yoneda, S. Horinouchi, A role for Hsc70 in regulating nucleocytoplasmic transport of a temperature-sensitive p53 (p53Val-135), J Biol Chem, 276 (2001) 14649-14657.

[62] H. Chen, Y. Wu, Y. Zhang, L. Jin, L. Luo, B. Xue, C. Lu, X. Zhang, Z. Yin, Hsp70 inhibits lipopolysaccharide-induced NF-kappaB activation by interacting with TRAF6 and inhibiting its ubiquitination, FEBS Lett, 580 (2006) 3145-3152.

[63] A. Mosoian, Intracellular and extracellular cytokine-like functions of prothymosin alpha: implications for the development of immunotherapies, Future Med Chem, 3 (2011) 1199-1208.

[64] R. Ran, A. Lu, L. Zhang, Y. Tang, H. Zhu, H. Xu, Y. Feng, C. Han, G. Zhou, A.C. Rigby, F.R. Sharp, Hsp70 promotes TNF-mediated apoptosis by binding IKK gamma and impairing NF-kappa B survival signaling, Genes Dev, 18 (2004) 1466-1481.

[65] T.P. Shanley, M.A. Ryan, T. Eaves-Pyles, H.R. Wong, Heat shock inhibits phosphorylation of I-kappaBalpha, Shock, 14 (2000) 447-450.

[66] C.G. Yoo, S. Lee, C.T. Lee, Y.W. Kim, S.K. Han, Y.S. Shim, Anti-inflammatory effect of heat shock protein induction is related to stabilization of I kappa B alpha through preventing I kappa B kinase activation in respiratory epithelial cells, J Immunol, 164 (2000) 5416-5423.

[67] E. Zorzi, P. Bonvini, Inducible hsp70 in the regulation of cancer cell survival: analysis of chaperone induction, expression and activity, Cancers (Basel), 3 (2011) 3921-3956.

[68] X. Feng, S. Bonni, K. Riabowol, HSP70 induction by ING proteins sensitizes cells to tumor necrosis factor alpha receptor-mediated apoptosis, Mol Cell Biol, 26 (2006) 9244-9255.

[69] A.H. Coles, S.N. Jones, The ING gene family in the regulation of cell growth and tumorigenesis, J Cell Physiol, 218 (2009) 45-57.

[70] A.R. Stankiewicz, G. Lachapelle, C.P. Foo, S.M. Radicioni, D.D. Mosser, Hsp70 inhibits heat-induced apoptosis upstream of mitochondria by preventing Bax translocation, J Biol Chem, 280 (2005) 38729-38739. 
[71] K. Ruchalski, H. Mao, Z. Li, Z. Wang, S. Gillers, Y. Wang, D.D. Mosser, V. Gabai, J.H. Schwartz, S.C. Borkan, Distinct hsp70 domains mediate apoptosis-inducing factor release and nuclear accumulation, J Biol Chem, 281 (2006) 7873-7880.

[72] F. Castellino, P.E. Boucher, K. Eichelberg, M. Mayhew, J.E. Rothman, A.N. Houghton, R.N. Germain, Receptor-mediated uptake of antigen/heat shock protein complexes results in major histocompatibility complex class I antigen presentation via two distinct processing pathways, J Exp Med, 191 (2000) 1957-1964.

[73] H.M. Beere, B.B. Wolf, K. Cain, D.D. Mosser, A. Mahboubi, T. Kuwana, P. Tailor, R.I. Morimoto, G.M. Cohen, D.R. Green, Heat-shock protein 70 inhibits apoptosis by preventing recruitment of procaspase-9 to the Apaf-1 apoptosome, Nat Cell Biol, 2 (2000) 469-475.

[74] P. Pandey, A. Saleh, A. Nakazawa, S. Kumar, S.M. Srinivasula, V. Kumar, R. Weichselbaum, C. Nalin, E.S. Alnemri, D. Kufe, S. Kharbanda, Negative regulation of cytochrome c-mediated oligomerization of Apaf-1 and activation of procaspase- 9 by heat shock protein 90, EMBO J, 19 (2000) 4310-4322.

[75] M. Jaattela, D. Wissing, K. Kokholm, T. Kallunki, M. Egeblad, Hsp70 exerts its antiapoptotic function downstream of caspase-3-like proteases, EMBO J, 17 (1998) 6124-6134.

[76] E.J. Duncan, M.E. Cheetham, J.P. Chapple, J. van der Spuy, The role of HSP70 and its cochaperones in protein misfolding, aggregation and disease, Subcell Biochem, 78 (2015) 243-273.

[77] P. Decker, S. Muller, Modulating poly (ADP-ribose) polymerase activity: potential for the prevention and therapy of pathogenic situations involving DNA damage and oxidative stress, Curr Pharm Biotechnol, 3 (2002) 275-283.

[78] P. Kotoglou, A. Kalaitzakis, P. Vezyraki, T. Tzavaras, L.K. Michalis, F. Dantzer, J.U. Jung, C. Angelidis, Hsp70 translocates to the nuclei and nucleoli, binds to XRCC1 and PARP-1, and protects HeLa cells from single-strand DNA breaks, Cell Stress Chaperones, 14 (2009) 391-406.

[79] Y. Matsumori, F.J. Northington, S.M. Hong, T. Kayama, R.A. Sheldon, Z.S. Vexler, D.M. Ferriero, P.R. Weinstein, J. Liu, Reduction of caspase-8 and -9 cleavage is associated with increased c-FLIP and increased binding of Apaf-1 and Hsp70 after neonatal hypoxic/ischemic injury in mice overexpressing Hsp70, Stroke, 37 (2006) 507-512.

[80] Q. Pang, W. Keeble, T.A. Christianson, G.R. Faulkner, G.C. Bagby, FANCC interacts with Hsp70 to protect hematopoietic cells from IFN-gamma/TNF-alpha-mediated cytotoxicity, EMBO J, 20 (2001) 4478-4489.

[81] Q. Pang, T.A. Christianson, W. Keeble, T. Koretsky, G.C. Bagby, The anti-apoptotic function of Hsp70 in the interferon-inducible double-stranded RNA-dependent protein kinasemediated death signaling pathway requires the Fanconi anemia protein, FANCC, J Biol Chem, 277 (2002) 49638-49643.

[82] G. Schett, C.W. Steiner, M. Groger, S. Winkler, W. Graninger, J. Smolen, Q. Xu, G. Steiner, Activation of Fas inhibits heat-induced activation of HSF1 and up-regulation of hsp70, FASEB journal : official publication of the Federation of American Societies for Experimental Biology, 13 (1999) 833-842.

[83] S.N. Liossis, X.Z. Ding, J.G. Kiang, G.C. Tsokos, Overexpression of the heat shock protein 70 enhances the TCR/CD3- and Fas/Apo-1/CD95-mediated apoptotic cell death in Jurkat T cells, J Immunol, 158 (1997) 5668-5675.

[84] C. Cande, N. Vahsen, C. Garrido, G. Kroemer, Apoptosis-inducing factor (AIF): caspaseindependent after all, Cell Death Differ, 11 (2004) 591-595.

[85] E.M. Creagh, R.J. Carmody, T.G. Cotter, Heat shock protein 70 inhibits caspase-dependent and -independent apoptosis in Jurkat T cells, Exp Cell Res, 257 (2000) 58-66. 
[86] L. Ravagnan, S. Gurbuxani, S.A. Susin, C. Maisse, E. Daugas, N. Zamzami, T. Mak, M. Jaattela, J.M. Penninger, C. Garrido, G. Kroemer, Heat-shock protein 70 antagonizes apoptosisinducing factor, Nat Cell Biol, 3 (2001) 839-843.

[87] J.C. Lui, S.K. Kong, Heat shock protein 70 inhibits the nuclear import of apoptosis-inducing factor to avoid DNA fragmentation in TF-1 cells during erythropoiesis, FEBS Lett, 581 (2007) 109-117.

[88] M. Kalinowska, W. Garncarz, M. Pietrowska, W.T. Garrard, P. Widlak, Regulation of the human apoptotic DNase/RNase endonuclease G: involvement of Hsp70 and ATP, Apoptosis, 10 (2005) 821-830.

[89] J. Nylandsted, M. Gyrd-Hansen, A. Danielewicz, N. Fehrenbacher, U. Lademann, M. Hoyer-Hansen, E. Weber, G. Multhoff, M. Rohde, M. Jaattela, Heat shock protein 70 promotes cell survival by inhibiting lysosomal membrane permeabilization, J Exp Med, 200 (2004) 425435.

[90] C. Bivik, I. Rosdahl, K. Ollinger, Hsp70 protects against UVB induced apoptosis by preventing release of cathepsins and cytochrome $\mathrm{c}$ in human melanocytes, Carcinogenesis, 28 (2007) 537-544.

[91] M.M. Simon, A. Reikerstorfer, A. Schwarz, C. Krone, T.A. Luger, M. Jaattela, T. Schwarz, Heat shock protein 70 overexpression affects the response to ultraviolet light in murine fibroblasts. Evidence for increased cell viability and suppression of cytokine release, J Clin Invest, 95 (1995) 926-933.

[92] D.R. Ciocca, S.K. Calderwood, Heat shock proteins in cancer: diagnostic, prognostic, predictive, and treatment implications, Cell Stress Chaperones, 10 (2005) 86-103.

[93] M. Abe, J.B. Manola, W.K. Oh, D.L. Parslow, D.J. George, C.L. Austin, P.W. Kantoff, Plasma levels of heat shock protein 70 in patients with prostate cancer: a potential biomarker for prostate cancer, Clin Prostate Cancer, 3 (2004) 49-53.

[94] S. Ray, Y. Lu, S.H. Kaufmann, W.C. Gustafson, J.E. Karp, I. Boldogh, A.P. Fields, A.R. Brasier, Genomic mechanisms of p210BCR-ABL signaling: induction of heat shock protein 70 through the GATA response element confers resistance to paclitaxel-induced apoptosis, J Biol Chem, 279 (2004) 35604-35615.

[95] M. Pocaly, V. Lagarde, G. Etienne, J.A. Ribeil, S. Claverol, M. Bonneu, F. Moreau-Gaudry, V. Guyonnet-Duperat, O. Hermine, J.V. Melo, M. Dupouy, B. Turcq, F.X. Mahon, J.M. Pasquet, Overexpression of the heat-shock protein 70 is associated to imatinib resistance in chronic myeloid leukemia, Leukemia, 21 (2007) 93-101.

[96] E.M. Eddy, Role of heat shock protein HSP70-2 in spermatogenesis, Rev Reprod, 4 (1999) 23-30.

[97] A. Targosz, P. Pierzchalski, A. Krawiec, U. Szczyrk, T. Brzozowski, S.J. Konturek, W.W. Pawlik, Helicobacter pylori inhibits expression of heat shock protein 70 (HSP70) in human epithelial cell line. Importance of Cag A protein, J Physiol Pharmacol, 57 (2006) 265-278.

[98] T. Morii, K. Ohtsuka, H. Ohnishi, K. Mochizuki, K. Satomi, Inhibition of heat-shock protein 27 expression eliminates drug resistance of osteosarcoma to zoledronic acid, Anticancer Res, 30 (2010) 3565-3571.

[99] L.M. Vargas-Roig, F.E. Gago, O. Tello, J.C. Aznar, D.R. Ciocca, Heat shock protein expression and drug resistance in breast cancer patients treated with induction chemotherapy, Int J Cancer, 79 (1998) 468-475.

[100] A. Brondani Da Rocha, A. Regner, I. Grivicich, D. Pretto Schunemann, C. Diel, G. Kovaleski, C. Brunetto De Farias, E. Mondadori, L. Almeida, A. Braga Filho, G. Schwartsmann, 
Radioresistance is associated to increased Hsp70 content in human glioblastoma cell lines, Int J Oncol, 25 (2004) 777-785.

[101] J.M. Seoane, P.I. Varela-Centelles, J.R. Ramirez, J. Cameselle-Teijeiro, M.A. Romero, J.M. Aguirre, Heat shock proteins (HSP70 and HSP27) as markers of epithelial dysplasia in oral leukoplakia, Am J Dermatopathol, 28 (2006) 417-422.

[102] M. Takashima, Y. Kuramitsu, Y. Yokoyama, N. Iizuka, T. Harada, M. Fujimoto, I. Sakaida, K. Okita, M. Oka, K. Nakamura, Proteomic analysis of autoantibodies in patients with hepatocellular carcinoma, Proteomics, 6 (2006) 3894-3900.

[103] M.P. Hatfield, S. Lovas, Role of Hsp70 in cancer growth and survival, Protein Pept Lett, 19 (2012) 616-624.

[104] J.A. Barnes, D.J. Dix, B.W. Collins, C. Luft, J.W. Allen, Expression of inducible Hsp70 enhances the proliferation of MCF-7 breast cancer cells and protects against the cytotoxic effects of hyperthermia, Cell Stress Chaperones, 6 (2001) 316-325.

[105] T.X. Xiang, Y. Li, Z. Jiang, A.L. Huang, C. Luo, B. Zhan, P.L. Wang, X.H. Tao, RNA interference-mediated silencing of the Hsp70 gene inhibits human gastric cancer cell growth and induces apoptosis in vitro and in vivo, Tumori, 94 (2008) 539-550.

[106] X.L. Du, T. Jiang, Z.Q. Wen, R. Gao, M. Cui, F. Wang, Silencing of heat shock protein 70 expression enhances radiotherapy efficacy and inhibits cell invasion in endometrial cancer cell line, Croat Med J, 50 (2009) 143-150.

[107] M.Y. Sherman, V.L. Gabai, Hsp70 in cancer: back to the future, Oncogene, 34 (2015) 4153-4161.

[108] Y. Maehara, E. Oki, T. Abe, E. Tokunaga, K. Shibahara, Y. Kakeji, K. Sugimachi, Overexpression of the heat shock protein HSP70 family and p53 protein and prognosis for patients with gastric cancer, Oncology, 58 (2000) 144-151.

[109] D. Brusa, E. Migliore, S. Garetto, M. Simone, L. Matera, Immunogenicity of 56 degrees C and UVC-treated prostate cancer is associated with release of HSP70 and HMGB1 from necrotic cells, The Prostate, 69 (2009) 1343-1352.

[110] S. Gunther, C. Ostheimer, S. Stangl, H.M. Specht, P. Mozes, M. Jesinghaus, D. Vordermark, S.E. Combs, F. Peltz, M.P. Jung, G. Multhoff, Correlation of Hsp70 Serum Levels with Gross Tumor Volume and Composition of Lymphocyte Subpopulations in Patients with Squamous Cell and Adeno Non-Small Cell Lung Cancer, Front Immunol, 6 (2015) 556.

[111] Y. Wang, S.R. McAlpine, Regulating the cytoprotective response in cancer cells using simultaneous inhibition of Hsp90 and Hsp70, Org Biomol Chem, 13 (2015) 2108-2116.

[112] J. Nylandsted, K. Brand, M. Jaattela, Heat shock protein 70 is required for the survival of cancer cells, Ann N Y Acad Sci, 926 (2000) 122-125.

[113] B. Nimmervoll, L.A. Chtcheglova, K. Juhasz, N. Cremades, F.A. Aprile, A. Sonnleitner, P. Hinterdorfer, L. Vigh, J. Preiner, Z. Balogi, Cell surface localised Hsp70 is a cancer specific regulator of clathrin-independent endocytosis, FEBS letters, 589 (2015) 2747-2753.

[114] T. Horibe, A. Torisawa, M. Kohno, K. Kawakami, Synergetic cytotoxic activity toward breast cancer cells enhanced by the combination of Antp-TPR hybrid peptide targeting Hsp90 and Hsp70-targeted peptide, BMC cancer, 14 (2014) 615.

[115] W. Wang, W. Ji, H. Hu, J. Ma, X. Li, W. Mei, Y. Xu, H. Hu, Y. Yan, Q. Song, Z. Li, C. $\mathrm{Su}$, Survivin promoter-regulated oncolytic adenovirus with Hsp70 gene exerts effective antitumor efficacy in gastric cancer immunotherapy, Oncotarget, 5 (2014) 150-160. 
[116] V. Cardile, C. Scifo, A. Russo, M. Falsaperla, G. Morgia, M. Motta, M. Renis, E. Imbriani, G. Silvestre, Involvement of HSP70 in resveratrol-induced apoptosis of human prostate cancer, Anticancer Res, 23 (2003) 4921-4926.

[117] S. Gurbuxani, E. Schmitt, C. Cande, A. Parcellier, A. Hammann, E. Daugas, I. Kouranti, C. Spahr, A. Pance, G. Kroemer, C. Garrido, Heat shock protein 70 binding inhibits the nuclear import of apoptosis-inducing factor, Oncogene, 22 (2003) 6669-6678.

[118] M. Jaattela, Over-expression of hsp70 confers tumorigenicity to mouse fibrosarcoma cells, International journal of cancer. Journal international du cancer, 60 (1995) 689-693.

[119] C. Garrido, E. Schmitt, C. Cande, N. Vahsen, A. Parcellier, G. Kroemer, HSP27 and HSP70: potentially oncogenic apoptosis inhibitors, Cell cycle, 2 (2003) 579-584.

[120] J.H. Lee, F. Schoffl, An Hsp70 antisense gene affects the expression of HSP70/HSC70, the regulation of HSF, and the acquisition of thermotolerance in transgenic Arabidopsis thaliana, Mol Gen Genet, 252 (1996) 11-19.

[121] E. Schmitt, L. Maingret, P.E. Puig, A.L. Rerole, F. Ghiringhelli, A. Hammann, E. Solary, G. Kroemer, C. Garrido, Heat shock protein 70 neutralization exerts potent antitumor effects in animal models of colon cancer and melanoma, Cancer Res, 66 (2006) 4191-4197.

[122] M.V. Powers, K. Jones, C. Barillari, I. Westwood, R.L. van Montfort, P. Workman, Targeting HSP70: the second potentially druggable heat shock protein and molecular chaperone?, Cell cycle, 9 (2010) 1542-1550.

[123] A.R. Goloudina, O.N. Demidov, C. Garrido, Inhibition of HSP70: a challenging anticancer strategy, Cancer letters, 325 (2012) 117-124.

[124] S. Kumar, M.S. Tomar, A. Acharya, HSF1-mediated regulation of tumor cell apoptosis: a novel target for cancer therapeutics, Future oncology (London, England), 9 (2013) 1573-1586.

[125] S.D. Westerheide, T.L. Kawahara, K. Orton, R.I. Morimoto, Triptolide, an inhibitor of the human heat shock response that enhances stress-induced cell death, J Biol Chem, 281 (2006) 9616-9622.

[126] N. Mujumdar, T.N. Mackenzie, V. Dudeja, R. Chugh, M.B. Antonoff, D. Borja-Cacho, V. Sangwan, R. Dawra, S.M. Vickers, A.K. Saluja, Triptolide induces cell death in pancreatic cancer cells by apoptotic and autophagic pathways, Gastroenterology, 139 (2010) 598-608.

[127] M.B. Antonoff, R. Chugh, D. Borja-Cacho, V. Dudeja, K.A. Clawson, S.J. Skube, B.S. Sorenson, D.A. Saltzman, S.M. Vickers, A.K. Saluja, Triptolide therapy for neuroblastoma decreases cell viability in vitro and inhibits tumor growth in vivo, Surgery, 146 (2009) 282-290.

[128] M. Li, J. Wang, J. Jing, H. Hua, T. Luo, L. Xu, R. Wang, D. Liu, Y. Jiang, Synergistic promotion of breast cancer cells death by targeting molecular chaperone GRP78 and heat shock protein 70, J Cell Mol Med, 13 (2009) 4540-4550.

[129] Z. Gong, J. Yang, M. Yang, F. Wang, Q. Wei, R.M. Tanguay, T. Wu, Benzo(a)pyrene inhibits expression of inducible heat shock protein 70 in vascular endothelial cells, Toxicol Lett, 166 (2006) 229-236.

[130] S. Banerjee Mustafi, P.K. Chakraborty, S. Raha, Modulation of Akt and ERK1/2 pathways by resveratrol in chronic myelogenous leukemia (CML) cells results in the downregulation of Hsp70, PLoS One, 5 (2010) e8719.

[131] Correction: peptides and aptamers targeting HSP70: a novel approach for anticancer chemotherapy, Cancer Res, 75 (2015) 902.

[132] J.I. Leu, J. Pimkina, A. Frank, M.E. Murphy, D.L. George, A small molecule inhibitor of inducible heat shock protein 70, Mol Cell, 36 (2009) 15-27. 
[133] C. Huang, J. Wang, Z. Chen, Y. Wang, W. Zhang, 2-phenylethynesulfonamide Prevents Induction of Pro-inflammatory Factors and Attenuates LPS-induced Liver Injury by Targeting NHE1-Hsp70 Complex in Mice, PLoS One, 8 (2013) e67582.

[134] A.J. Steele, A.G. Prentice, A.V. Hoffbrand, B.C. Yogashangary, S.M. Hart, M.W. Lowdell, E.R. Samuel, J.M. North, E.P. Nacheva, A. Chanalaris, P. Kottaridis, K. Cwynarski, R.G. Wickremasinghe, 2-Phenylacetylenesulfonamide (PAS) induces p53-independent apoptotic killing of B-chronic lymphocytic leukemia (CLL) cells, Blood, 114 (2009) 1217-1225.

[135] D.S. Williamson, J. Borgognoni, A. Clay, Z. Daniels, P. Dokurno, M.J. Drysdale, N. Foloppe, G.L. Francis, C.J. Graham, R. Howes, A.T. Macias, J.B. Murray, R. Parsons, T. Shaw, A.E. Surgenor, L. Terry, Y. Wang, M. Wood, A.J. Massey, Novel adenosine-derived inhibitors of $70 \mathrm{kDa}$ heat shock protein, discovered through structure-based design, J Med Chem, 52 (2009) 1510-1513.

[136] A.J. Massey, D.S. Williamson, H. Browne, J.B. Murray, P. Dokurno, T. Shaw, A.T. Macias, Z. Daniels, S. Geoffroy, M. Dopson, P. Lavan, N. Matassova, G.L. Francis, C.J. Graham, R. Parsons, Y. Wang, A. Padfield, M. Comer, M.J. Drysdale, M. Wood, A novel, small molecule inhibitor of Hsc70/Hsp70 potentiates Hsp90 inhibitor induced apoptosis in HCT116 colon carcinoma cells, Cancer Chemother Pharmacol, 66 (2010) 535-545.

[137] U.K. Jinwal, Y. Miyata, J. Koren, 3rd, J.R. Jones, J.H. Trotter, L. Chang, J. O'Leary, D. Morgan, D.C. Lee, C.L. Shults, A. Rousaki, E.J. Weeber, E.R. Zuiderweg, J.E. Gestwicki, C.A. Dickey, Chemical manipulation of hsp70 ATPase activity regulates tau stability, J Neurosci, 29 (2009) 12079-12088.

[138] D. Mamelak, C. Lingwood, The ATPase domain of hsp70 possesses a unique binding specificity for 3'-sulfogalactolipids, J Biol Chem, 276 (2001) 449-456.

[139] J. Boulanger, D. Faulds, E.M. Eddy, C.A. Lingwood, Members of the $70 \mathrm{kDa}$ heat shock protein family specifically recognize sulfoglycolipids: role in gamete recognition and mycoplasma-related infertility, J Cell Physiol, 165 (1995) 7-17.

[140] S.P. Ermakova, B.S. Kang, B.Y. Choi, H.S. Choi, T.F. Schuster, W.Y. Ma, A.M. Bode, Z. Dong, (-)-Epigallocatechin gallate overcomes resistance to etoposide-induced cell death by targeting the molecular chaperone glucose-regulated protein 78, Cancer Res, 66 (2006) 92609269.

[141] D.R. Williams, S.K. Ko, S. Park, M.R. Lee, I. Shin, An apoptosis-inducing small molecule that binds to heat shock protein 70, Angew Chem Int Ed Engl, 47 (2008) 7466-7469.

[142] G.M. Balaburski, J.I. Leu, N. Beeharry, S. Hayik, M.D. Andrake, G. Zhang, M. Herlyn, J. Villanueva, R.L. Dunbrack, Jr., T. Yen, D.L. George, M.E. Murphy, A modified HSP70 inhibitor shows broad activity as an anticancer agent, Molecular cancer research : MCR, 11 (2013) 219229.

[143] G. Kragol, S. Lovas, G. Varadi, B.A. Condie, R. Hoffmann, L. Otvos, Jr., The antibacterial peptide pyrrhocoricin inhibits the ATPase actions of DnaK and prevents chaperone-assisted protein folding, Biochemistry, 40 (2001) 3016-3026.

[144] M. Otaka, S. Yamamoto, K. Ogasawara, Y. Takaoka, S. Noguchi, T. Miyazaki, A. Nakai, M. Odashima, T. Matsuhashi, S. Watanabe, H. Itoh, The induction mechanism of the molecular chaperone HSP70 in the gastric mucosa by Geranylgeranylacetone (HSP-inducer), Biochem Biophys Res Commun, 353 (2007) 399-404.

[145] M. Liebscher, G. Jahreis, C. Lucke, S. Grabley, S. Raina, C. Schiene-Fischer, Fatty acyl benzamido antibacterials based on inhibition of DnaK-catalyzed protein folding, J Biol Chem, 282 (2007) 4437-4446. 
[146] K. Koya, Y. Li, H. Wang, T. Ukai, N. Tatsuta, M. Kawakami, Shishido, L.B. Chen, MKT077, a novel rhodacyanine dye in clinical trials, exhibits anticarcinoma activity in preclinical studies based on selective mitochondrial accumulation, Cancer Res, 56 (1996) 538-543.

[147] C.C. Deocaris, N. Widodo, B.G. Shrestha, K. Kaur, M. Ohtaka, K. Yamasaki, S.C. Kaul, R. Wadhwa, Mortalin sensitizes human cancer cells to MKT-077-induced senescence, Cancer Lett, 252 (2007) 259-269.

[148] C.G. Evans, S. Wisen, J.E. Gestwicki, Heat shock proteins 70 and 90 inhibit early stages of amyloid beta-(1-42) aggregation in vitro, J Biol Chem, 281 (2006) 33182-33191.

[149] C.M. Wright, S.P. Seguin, S.W. Fewell, H. Zhang, C. Ishwad, A. Vats, C.A. Lingwood, P. Wipf, E. Fanning, J.M. Pipas, J.L. Brodsky, Inhibition of Simian Virus 40 replication by targeting the molecular chaperone function and ATPase activity of T antigen, Virus Res, 141 (2009) 71-80.

[150] F. Yi, L. Regan, A novel class of small molecule inhibitors of Hsp90, ACS Chem Biol, 3 (2008) 645-654.

[151] C. Roodveldt, C.W. Bertoncini, A. Andersson, A.T. van der Goot, S.T. Hsu, R. FernandezMontesinos, J. de Jong, T.J. van Ham, E.A. Nollen, D. Pozo, J. Christodoulou, C.M. Dobson, Chaperone proteostasis in Parkinson's disease: stabilization of the Hsp70/alpha-synuclein complex by Hip, EMBO J, 28 (2009) 3758-3770.

[152] C.H. Yun, S.Y. Yoon, T.T. Nguyen, H.Y. Cho, T.H. Kim, S.T. Kim, B.C. Kim, Y.S. Hong, S.J. Kim, H.J. Lee, Geldanamycin inhibits TGF-beta signaling through induction of Hsp70, Arch Biochem Biophys, 495 (2010) 8-13.

[153] M.V. Powers, P.A. Clarke, P. Workman, Death by chaperone: HSP90, HSP70 or both?, Cell Cycle, 8 (2009) 518-526.

[154] M.V. Powers, P.A. Clarke, P. Workman, Dual targeting of HSC70 and HSP72 inhibits HSP90 function and induces tumor-specific apoptosis, Cancer Cell, 14 (2008) 250-262.

[155] H. Jensen, L. Andresen, K.A. Hansen, S. Skov, Cell-surface expression of Hsp70 on hematopoietic cancer cells after inhibition of HDAC activity, J Leukoc Biol, 86 (2009) 923-932. [156] F. Chalmin, S. Ladoire, G. Mignot, J. Vincent, M. Bruchard, J.P. Remy-Martin, W. Boireau, A. Rouleau, B. Simon, D. Lanneau, A. De Thonel, G. Multhoff, A. Hamman, F. Martin, B. Chauffert, E. Solary, L. Zitvogel, C. Garrido, B. Ryffel, C. Borg, L. Apetoh, C. Rebe, F. Ghiringhelli, Membrane-associated Hsp72 from tumor-derived exosomes mediates STAT3dependent immunosuppressive function of mouse and human myeloid-derived suppressor cells, $\mathrm{J}$ Clin Invest, 120 (2010) 457-471.

[157] S. Kumar, A. Acharya, Chelerythrine induces reactive oxygen species-dependent mitochondrial apoptotic pathway in a murine T cell lymphoma, Tumour Biol, 35 (2014) 129140.

[158] S. Kumar, P. Deepak, S. Kumar, P.K. Gautam, A. Acharya, A benzophenanthridine alkaloid, chelerythrine induces apoptosis in vitro in a Dalton's lymphoma, J Cancer Res Ther, 9 (2013) 693-700.

[159] S. Kumar, P. Deepak, S. Kumar, Jr., D. Kishore, A. Acharya, Autologous Hsp70 induces antigen specific Th1 immune responses in a murine T-cell lymphoma, Immunol Invest, 38 (2009) 449-465.

[160] M.A. Bausero, D.T. Page, E. Osinaga, A. Asea, Surface expression of Hsp25 and Hsp72 differentially regulates tumor growth and metastasis, Tumour Biol, 25 (2004) 243-251. 
[161] M.A. Bausero, R. Gastpar, G. Multhoff, A. Asea, Alternative mechanism by which IFNgamma enhances tumor recognition: active release of heat shock protein 72, J Immunol, 175 (2005) 2900-2912.

[162] M.C. Kuppner, R. Gastpar, S. Gelwer, E. Nossner, O. Ochmann, A. Scharner, R.D. Issels, The role of heat shock protein (hsp70) in dendritic cell maturation: hsp70 induces the maturation of immature dendritic cells but reduces DC differentiation from monocyte precursors, Eur $\mathrm{J}$ Immunol, 31 (2001) 1602-1609.

[163] D. Schilling, M. Gehrmann, C. Steinem, A. De Maio, A.G. Pockley, M. Abend, M. Molls, G. Multhoff, Binding of heat shock protein 70 to extracellular phosphatidylserine promotes killing of normoxic and hypoxic tumor cells, FASEB J, 23 (2009) 2467-2477.

[164] A. Asea, S.K. Kraeft, E.A. Kurt-Jones, M.A. Stevenson, L.B. Chen, R.W. Finberg, G.C. Koo, S.K. Calderwood, HSP70 stimulates cytokine production through a CD14-dependant pathway, demonstrating its dual role as a chaperone and cytokine, Nat Med, 6 (2000) 435-442.

[165] S.S. Mambula, S.K. Calderwood, Heat shock protein 70 is secreted from tumor cells by a nonclassical pathway involving lysosomal endosomes, J Immunol, 177 (2006) 7849-7857.

[166] V.L. Vega, M. Rodriguez-Silva, T. Frey, M. Gehrmann, J.C. Diaz, C. Steinem, G. Multhoff, N. Arispe, A. De Maio, Hsp70 translocates into the plasma membrane after stress and is released into the extracellular environment in a membrane-associated form that activates macrophages, J Immunol, 180 (2008) 4299-4307.

[167] P. Srivastava, Roles of heat-shock proteins in innate and adaptive immunity, Nat Rev Immunol, 2 (2002) 185-194.

[168] C.V. Nicchitta, Re-evaluating the role of heat-shock protein-peptide interactions in tumour immunity, Nat Rev Immunol, 3 (2003) 427-432.

[169] H. Udono, P.K. Srivastava, Heat shock protein 70-associated peptides elicit specific cancer immunity, J Exp Med, 178 (1993) 1391-1396.

[170] A. Asea, M. Rehli, E. Kabingu, J.A. Boch, O. Bare, P.E. Auron, M.A. Stevenson, S.K. Calderwood, Novel signal transduction pathway utilized by extracellular HSP70: role of toll-like receptor (TLR) 2 and TLR4, J Biol Chem, 277 (2002) 15028-15034.

[171] G. Multhoff, C. Botzler, L. Jennen, J. Schmidt, J. Ellwart, R. Issels, Heat shock protein 72 on tumor cells: a recognition structure for natural killer cells, J Immunol, 158 (1997) 4341-4350.

[172] S.M. Todryk, A.A. Melcher, A.G. Dalgleish, R.G. Vile, Heat shock proteins refine the danger theory, Immunology, 99 (2000) 334-337.

[173] C. Castelli, L. Rivoltini, F. Rini, F. Belli, A. Testori, M. Maio, V. Mazzaferro, J. Coppa, P.K. Srivastava, G. Parmiani, Heat shock proteins: biological functions and clinical application as personalized vaccines for human cancer, Cancer Immunol Immunother, 53 (2004) 227-233.

[174] D. Arnold-Schild, D. Hanau, D. Spehner, C. Schmid, H.G. Rammensee, H. de la Salle, H. Schild, Cutting edge: receptor-mediated endocytosis of heat shock proteins by professional antigen-presenting cells, J Immunol, 162 (1999) 3757-3760.

[175] S. Basu, R.J. Binder, T. Ramalingam, P.K. Srivastava, CD91 is a common receptor for heat shock proteins gp96, hsp90, hsp70, and calreticulin, Immunity, 14 (2001) 303-313.

[176] H. Singh-Jasuja, N. Hilf, H.U. Scherer, D. Arnold-Schild, H.G. Rammensee, R.E. Toes, H. Schild, The heat shock protein gp96: a receptor-targeted cross-priming carrier and activator of dendritic cells, Cell Stress Chaperones, 5 (2000) 462-470.

[177] H. Sondermann, T. Becker, M. Mayhew, F. Wieland, F.U. Hartl, Characterization of a receptor for heat shock protein 70 on macrophages and monocytes, Biol Chem, 381 (2000) 11651174. 
[178] R.J. Binder, N.E. Blachere, P.K. Srivastava, Heat shock protein-chaperoned peptides but not free peptides introduced into the cytosol are presented efficiently by major histocompatibility complex I molecules, J Biol Chem, 276 (2001) 17163-17171.

[179] H. Singh-Jasuja, R.E. Toes, P. Spee, C. Munz, N. Hilf, S.P. Schoenberger, P. RicciardiCastagnoli, J. Neefjes, H.G. Rammensee, D. Arnold-Schild, H. Schild, Cross-presentation of glycoprotein 96-associated antigens on major histocompatibility complex class I molecules requires receptor-mediated endocytosis, J Exp Med, 191 (2000) 1965-1974.

[180] P.K. Srivastava, A. Menoret, S. Basu, R.J. Binder, K.L. McQuade, Heat shock proteins come of age: primitive functions acquire new roles in an adaptive world, Immunity, 8 (1998) 657-665.

[181] A.D. Doody, J.T. Kovalchin, M.A. Mihalyo, A.T. Hagymasi, C.G. Drake, A.J. Adler, Glycoprotein 96 can chaperone both MHC class I- and class II-restricted epitopes for in vivo presentation, but selectively primes CD8+ T cell effector function, J Immunol, 172 (2004) 60876092.

[182] J.B. Flechtner, K.P. Cohane, S. Mehta, P. Slusarewicz, A.K. Leonard, B.H. Barber, D.L. Levey, S. Andjelic, High-affinity interactions between peptides and heat shock protein 70 augment CD8+ T lymphocyte immune responses, J Immunol, 177 (2006) 1017-1027.

[183] C. Habich, K. Baumgart, H. Kolb, V. Burkart, The receptor for heat shock protein 60 on macrophages is saturable, specific, and distinct from receptors for other heat shock proteins, $\mathrm{J}$ Immunol, 168 (2002) 569-576.

[184] R.M. Vabulas, P. Ahmad-Nejad, C. da Costa, T. Miethke, C.J. Kirschning, H. Hacker, H. Wagner, Endocytosed HSP60s use toll-like receptor 2 (TLR2) and TLR4 to activate the toll/interleukin-1 receptor signaling pathway in innate immune cells, J Biol Chem, 276 (2001) 31332-31339.

[185] H. Bendz, S.C. Ruhland, M.J. Pandya, O. Hainzl, S. Riegelsberger, C. Brauchle, M.P. Mayer, J. Buchner, R.D. Issels, E. Noessner, Human heat shock protein 70 enhances tumor antigen presentation through complex formation and intracellular antigen delivery without innate immune signaling, J Biol Chem, 282 (2007) 31688-31702.

[186] M. Haug, C.P. Schepp, H. Kalbacher, G.E. Dannecker, U. Holzer, 70-kDa heat shock proteins: specific interactions with HLA-DR molecules and their peptide fragments, Eur J Immunol, 37 (2007) 1053-1063.

[187] P. Matzinger, The danger model: a renewed sense of self, Science, 296 (2002) 301-305.

[188] H. Zhang, W. Huang, Fusion proteins of Hsp70 with tumor-associated antigen acting as a potent tumor vaccine and the C-terminal peptide-binding domain of Hsp70 being essential in inducing antigen-independent anti-tumor response in vivo, Cell Stress Chaperones, 11 (2006) 216-226.

[189] L. Sanchez-Perez, T. Kottke, G.A. Daniels, R.M. Diaz, J. Thompson, J. Pulido, A. Melcher, R.G. Vile, Killing of normal melanocytes, combined with heat shock protein 70 and CD40L expression, cures large established melanomas, J Immunol, 177 (2006) 4168-4177.

[190] R.C. Reed, B. Berwin, J.P. Baker, C.V. Nicchitta, GRP94/gp96 elicits ERK activation in murine macrophages. A role for endotoxin contamination in NF-kappa B activation and nitric oxide production, J Biol Chem, 278 (2003) 31853-31860.

[191] T. Kottke, L. Sanchez-Perez, R.M. Diaz, J. Thompson, H. Chong, K. Harrington, S.K. Calderwood, J. Pulido, N. Georgopoulos, P. Selby, A. Melcher, R. Vile, Induction of hsp70mediated Th17 autoimmunity can be exploited as immunotherapy for metastatic prostate cancer, Cancer Res, 67 (2007) 11970-11979. 
[192] J. Jimbo, K. Sato, T. Hosoki, M. Shindo, K. Ikuta, Y. Torimoto, Y. Kohgo, Induction of leukemia-specific antibodies by immunotherapy with leukemia-cell-derived heat shock protein 70, Cancer Sci, 99 (2008) 1427-1434.

[193] D. Toomey, H. Conroy, A.G. Jarnicki, S.C. Higgins, C. Sutton, K.H. Mills, Therapeutic vaccination with dendritic cells pulsed with tumor-derived Hsp70 and a COX-2 inhibitor induces protective immunity against B16 melanoma, Vaccine, 26 (2008) 3540-3549.

[194] O. Faure, S. Graff-Dubois, P.M. Alves, S. Cornet, M.T. Duffour, A. Scardino, D.A. Gross, I. Miconnet, M. Salcedo, S. Chouaib, F.A. Lemonnier, J.P. Abastado, K. Kosmatopoulos, Induction of multiple CD8+ T cell responses against the inducible Hsp70 employing an Hsp70 oligoepitope peptide, Oncol Rep, 17 (2007) 679-685.

[195] B. Liu, D. Ye, X. Song, X. Zhao, L. Yi, J. Song, Z. Zhang, Q. Zhao, A novel therapeutic fusion protein vaccine by two different families of heat shock proteins linked with HPV16 E7 generates potent antitumor immunity and antiangiogenesis, Vaccine, 26 (2008) 1387-1396.

[196] Y. Enomoto, A. Bharti, A.A. Khaleque, B. Song, C. Liu, V. Apostolopoulos, P.X. Xing, S.K. Calderwood, J. Gong, Enhanced immunogenicity of heat shock protein 70 peptide complexes from dendritic cell-tumor fusion cells, J Immunol, 177 (2006) 5946-5955.

[197] D.R. Ciocca, P. Frayssinet, F.D. Cuello-Carrion, A pilot study with a therapeutic vaccine based on hydroxyapatite ceramic particles and self-antigens in cancer patients, Cell Stress Chaperones, 12 (2007) 33-43.

[198] L. Wooldridge, A. Lissina, J. Vernazza, E. Gostick, B. Laugel, S.L. Hutchinson, F. Mirza, P.R. Dunbar, J.M. Boulter, M. Glick, V. Cerundolo, H.A. van den Berg, D.A. Price, A.K. Sewell, Enhanced immunogenicity of CTL antigens through mutation of the CD8 binding MHC class I invariant region, Eur J Immunol, 37 (2007) 1323-1333.

[199] Y. Zeng, X. Chen, N. Larmonier, C. Larmonier, G. Li, M. Sepassi, M. Marron, S. Andreansky, E. Katsanis, Natural killer cells play a key role in the antitumor immunity generated by chaperone-rich cell lysate vaccination, Int J Cancer, 119 (2006) 2624-2631.

[200] C. Gross, D. Hansch, R. Gastpar, G. Multhoff, Interaction of heat shock protein 70 peptide with NK cells involves the NK receptor CD94, Biol Chem, 384 (2003) 267-279.

[201] C. Botzler, G. Li, R.D. Issels, G. Multhoff, Definition of extracellular localized epitopes of Hsp70 involved in an NK immune response, Cell Stress Chaperones, 3 (1998) 6-11.

[202] G. Multhoff, L. Mizzen, C.C. Winchester, C.M. Milner, S. Wenk, G. Eissner, H.H. Kampinga, B. Laumbacher, J. Johnson, Heat shock protein 70 (Hsp70) stimulates proliferation and cytolytic activity of natural killer cells, Exp Hematol, 27 (1999) 1627-1636.

[203] S. Stangl, A. Wortmann, U. Guertler, G. Multhoff, Control of metastasized pancreatic carcinomas in SCID/beige mice with human IL-2/TKD-activated NK cells, J Immunol, 176 (2006) 6270-6276.

[204] H.M. Specht, N. Ahrens, C. Blankenstein, T. Duell, R. Fietkau, U.S. Gaipl, C. Gunther, S. Gunther, G. Habl, H. Hautmann, M. Hautmann, R.M. Huber, M. Molls, R. Offner, C. Rodel, F. Rodel, M. Schutz, S.E. Combs, G. Multhoff, Heat Shock Protein 70 (Hsp70) Peptide Activated Natural Killer (NK) Cells for the Treatment of Patients with Non-Small Cell Lung Cancer (NSCLC) after Radiochemotherapy (RCTx) - From Preclinical Studies to a Clinical Phase II Trial, Front Immunol, 6 (2015) 162.

[205] I. Gutcher, P.R. Webb, N.G. Anderson, The isoform-specific regulation of apoptosis by protein kinase C, Cell Mol Life Sci, 60 (2003) 1061-1070.

[206] D. Lanneau, M. Brunet, E. Frisan, E. Solary, M. Fontenay, C. Garrido, Heat shock proteins: essential proteins for apoptosis regulation, J Cell Mol Med, 12 (2008) 743-761. 
[207] A.S. Sreedhar, P. Csermely, Heat shock proteins in the regulation of apoptosis: new strategies in tumor therapy: a comprehensive review, Pharmacol Ther, 101 (2004) 227-257.

[208] W. Wang, B. Vinocur, O. Shoseyov, A. Altman, Role of plant heat-shock proteins and molecular chaperones in the abiotic stress response, Trends Plant Sci, 9 (2004) 244-252.

[209] W.C. Earnshaw, L.M. Martins, S.H. Kaufmann, Mammalian caspases: structure, activation, substrates, and functions during apoptosis, Annu Rev Biochem, 68 (1999) 383-424. 
Hsp70

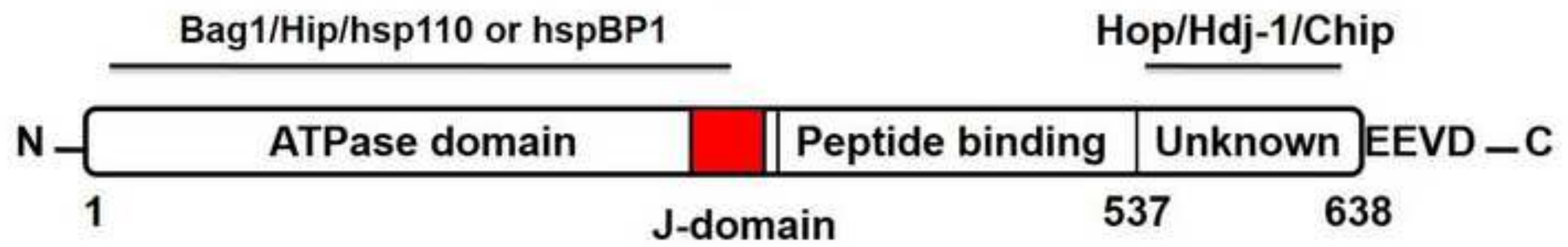

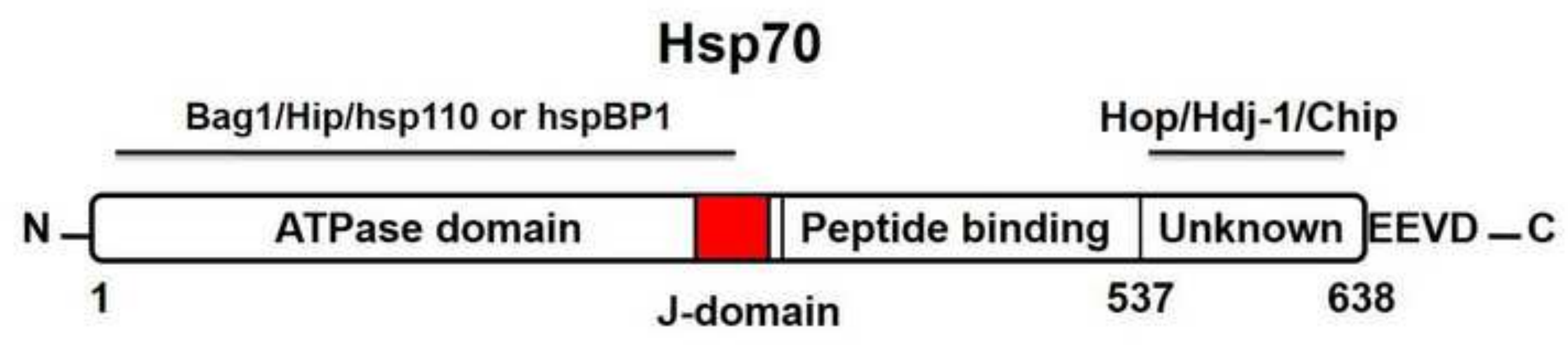

J-domain




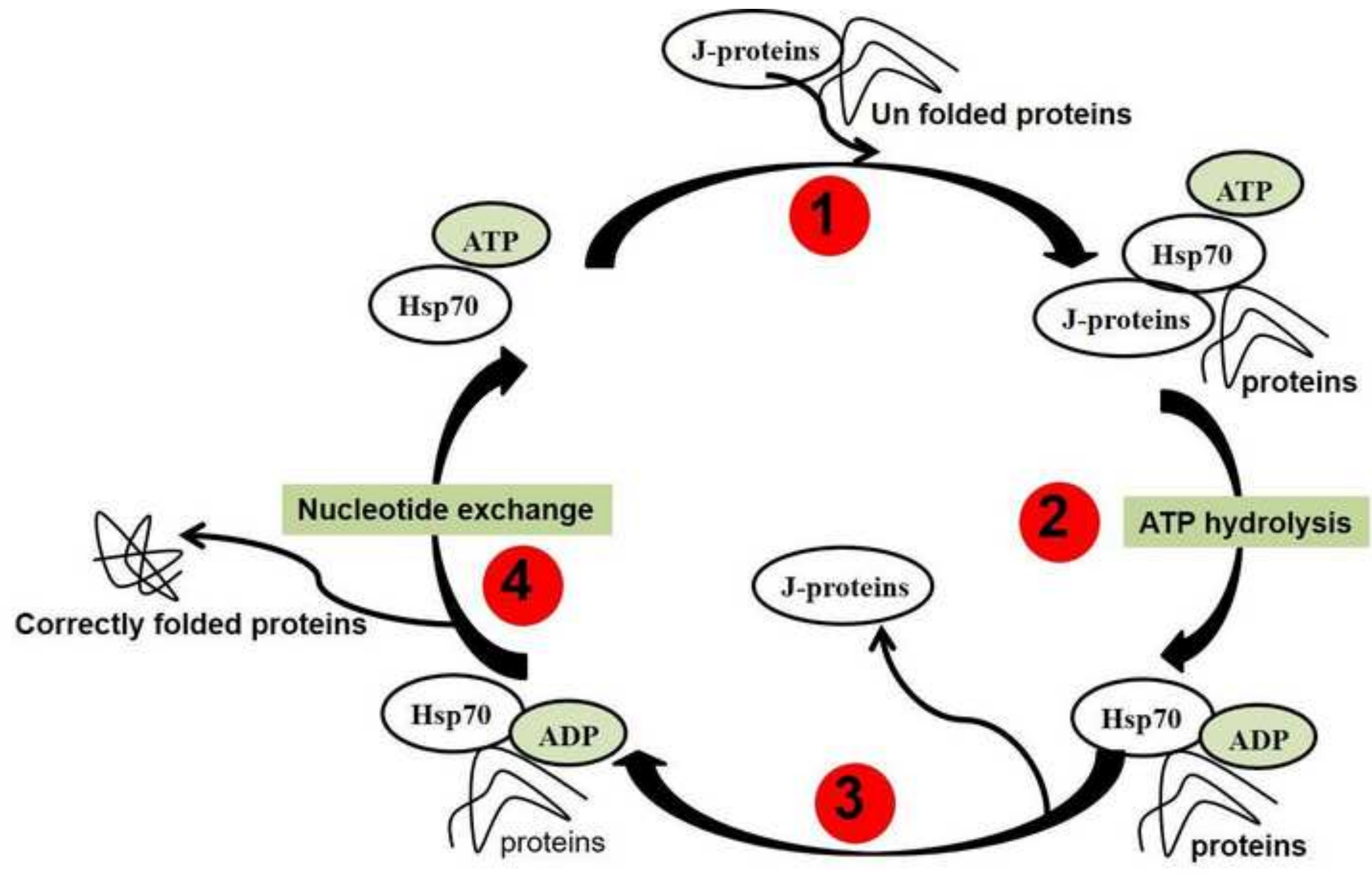




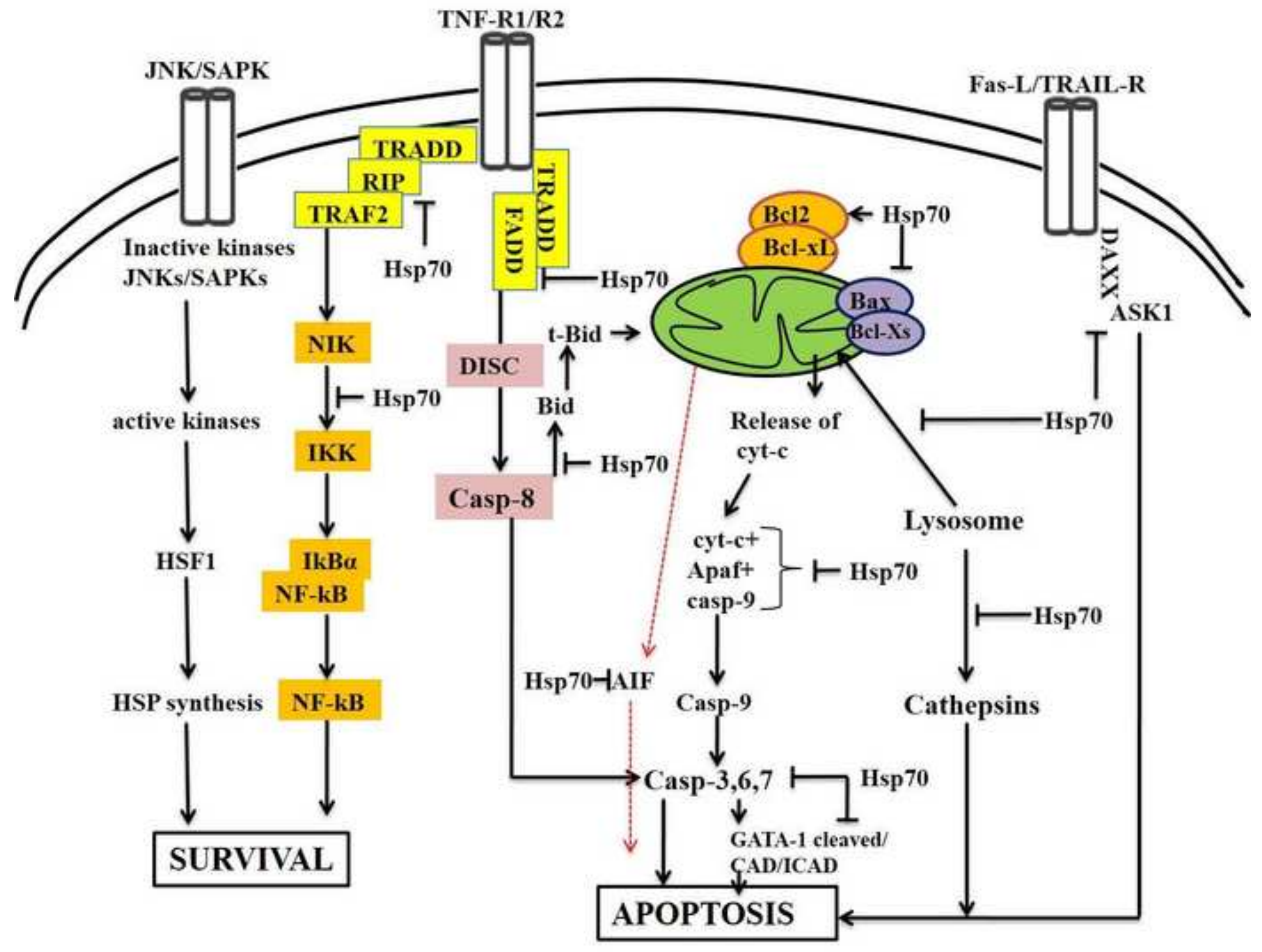




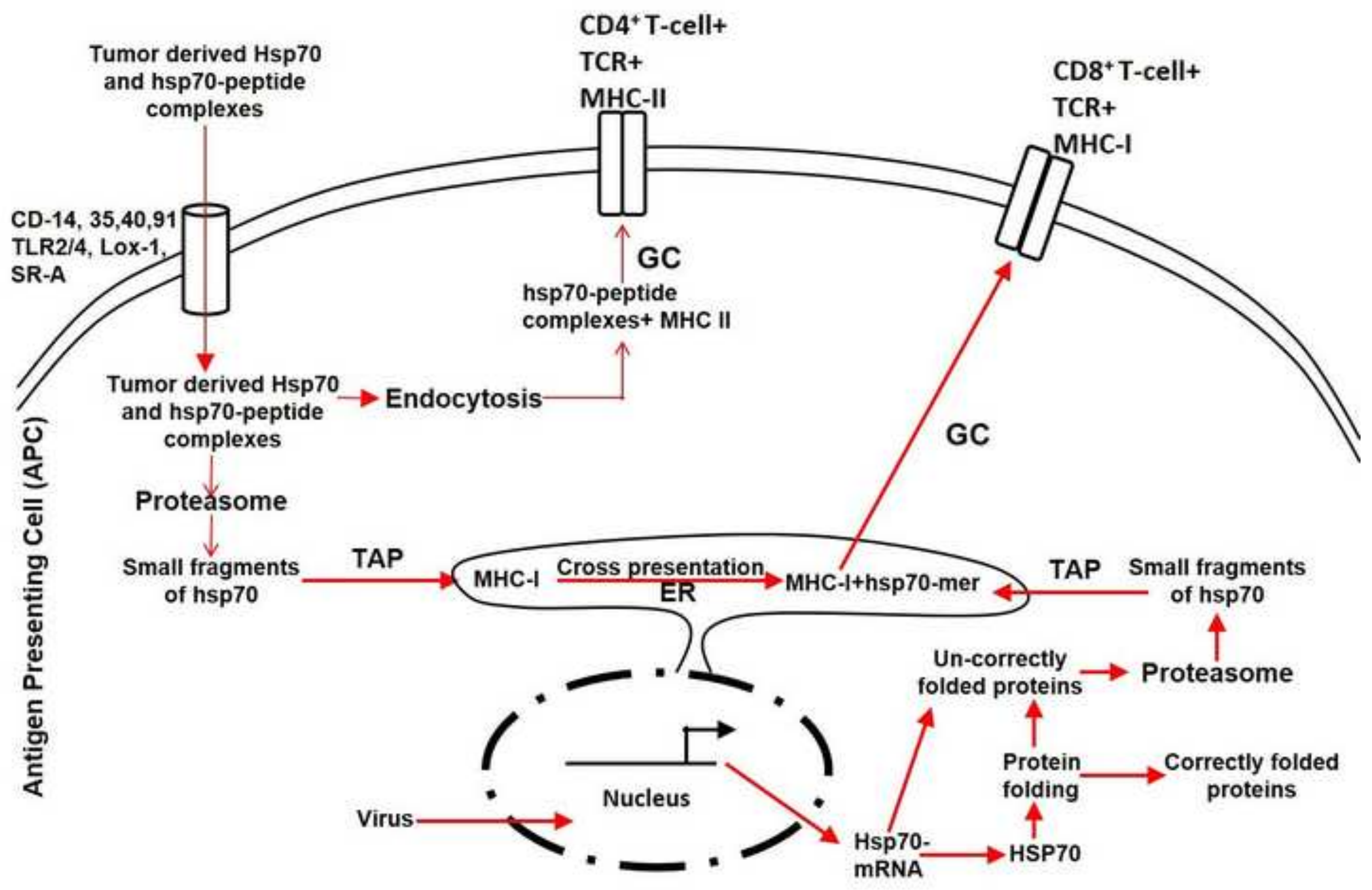




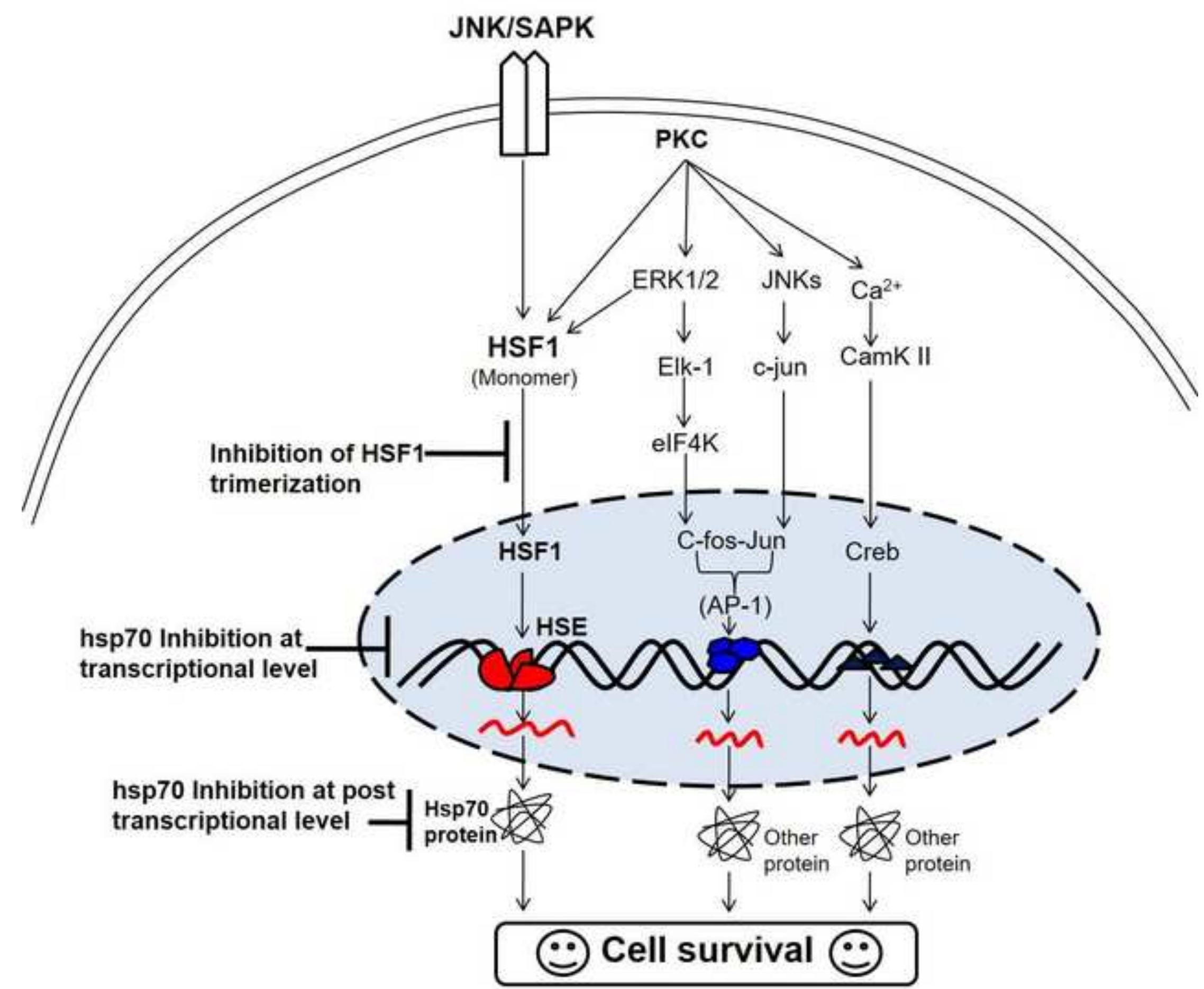

